Provided for non-commercial research and education use. Not for reproduction, distribution or commercial use.

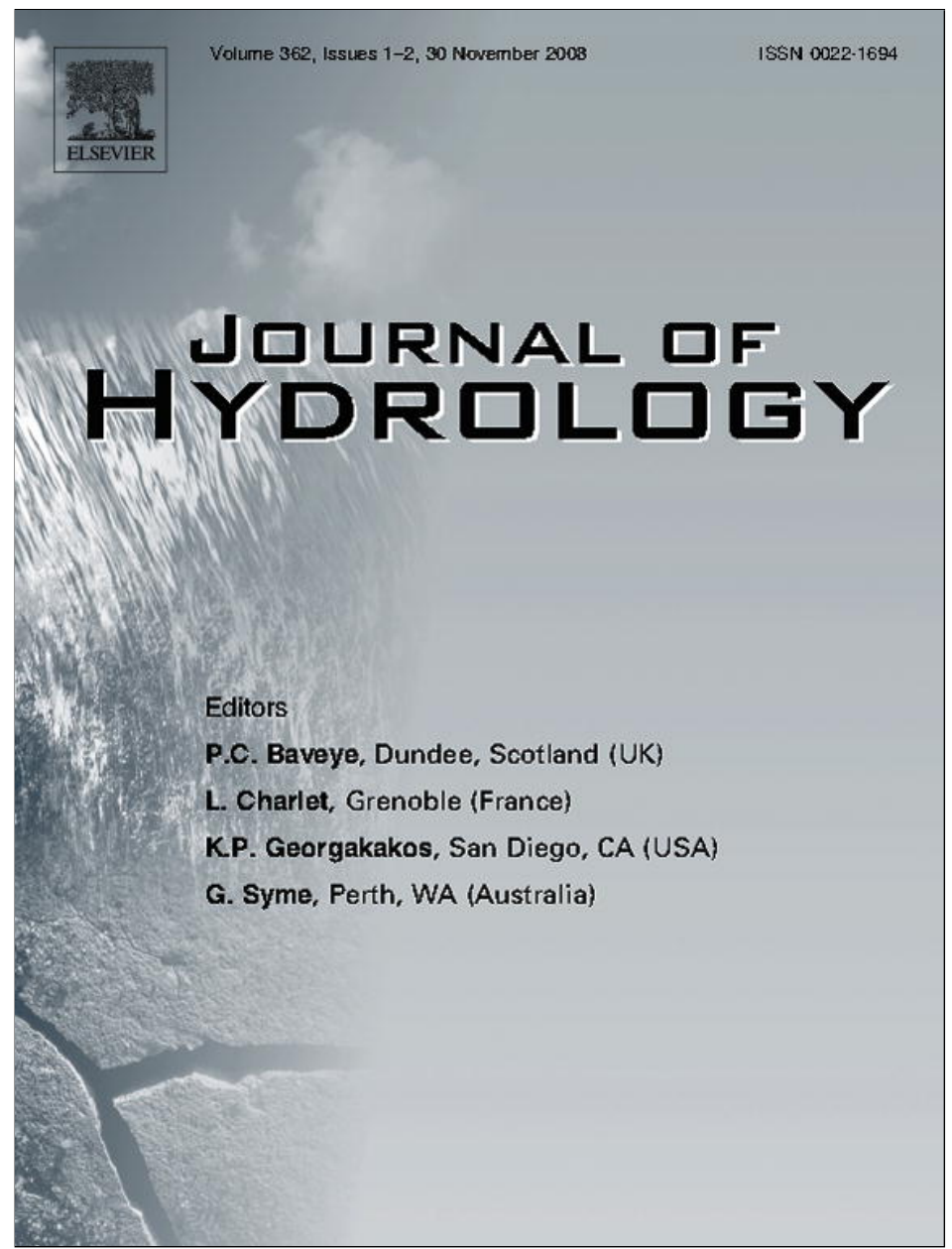

This article appeared in a journal published by Elsevier. The attached copy is furnished to the author for internal non-commercial research and education use, including for instruction at the authors institution and sharing with colleagues.

Other uses, including reproduction and distribution, or selling or licensing copies, or posting to personal, institutional or third party websites are prohibited.

In most cases authors are permitted to post their version of the article (e.g. in Word or Tex form) to their personal website or institutional repository. Authors requiring further information regarding Elsevier's archiving and manuscript policies are encouraged to visit:

http://www.elsevier.com/copyright 


\title{
Analysis of energy fluxes and vegetation-atmosphere parameters in irrigated and natural ecosystems of semi-arid Brazil
}

\author{
A.H. de Castro Teixeira a,b,* W.G.M. Bastiaanssen ${ }^{\text {c,d }}{ }^{\text {, M.D. Ahmad }}{ }^{\text {e, }}$, \\ M.S.B. Moura ${ }^{a}$, M.G. Bos ${ }^{f}$
}

a Department of Agrometerology, BR 428, CP 23, Embrapa Semi-Árido, P.O. Box 23, 56302-970 Petrolina, Pernambuco, PE, Brazil

b Wageningen University and Research Centre, Centre for Water and Climate, Droevendaalsesteeg 4, 6700 AA, P.O. Box 47, Wageningen, The Netherlands

' WaterWatch, Generaal Foulkesweg 28, 6703 BS, Wageningen, The Netherlands

'Delft University of Technology, Stevinweg 1, 2600 GA, Delft, The Netherlands

e Formerly with International Water Management Institute, P.O. Box 2075, Colombo, Sri Lanka

${ }^{f}$ Formerly with International Institute for Geo-Information Science and Earth Observations, P.O. Box 6, 7500 AA Enschede, The Netherlands

Received 5 June 2008; received in revised form 11 August 2008; accepted 14 August 2008

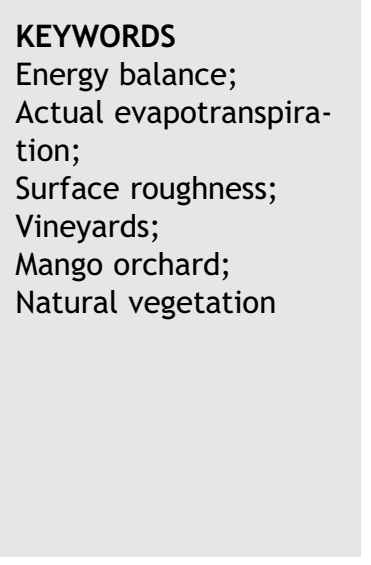

\begin{abstract}
Summary Knowledge on evapotranspiration is essential in quantifying water use depletion and to allocate scarce water resources to competing uses. Despite that an extensive literature describes the theoretical mechanisms of turbulent water vapour transport above and within crop canopies fewer studies have examined land surface parameters within composite landscapes of irrigated crops and semi-arid natural vegetation. Aiming to improve parameterizations of the radiation and energy balance in irrigated crops and natural vegetation, micro-climatic measurements were carried out on irrigated land (vineyards and mango orchard) and natural vegetation (caatinga) in the semi-arid zone of the São Francisco River basin (Brazil) from 2002 to 2005. The fractions of $24 \mathrm{~h}$ incident solar radiation available for net radiation were $46 \%, 55 \%, 51 \%$ and $53 \%$, for wine grape, table grape, mango orchard and caatinga, respectively. Daily evaporative fractions of the net available energy used as latent heat flux $(\lambda E)$ were $0.80,0.88,0.75$ and 0.33 respectively. The daylight values of bulk surface resistances $\left(r_{\mathrm{s}}\right)$ averaged $128 \mathrm{~s} \mathrm{~m}^{-1}, 73 \mathrm{~s} \mathrm{~m}^{-1}$, $133 \mathrm{~s} \mathrm{~m}^{-1}$ and $1940 \mathrm{~s} \mathrm{~m}^{-1}$ for wine grape, table grape, mango orchard and caatinga,
\end{abstract}

\footnotetext{
* Corresponding author. Address: Department of Agrometerology, BR 428, CP 23, Embrapa Semi-Árido, P.O. Box 23, 56302-970 Petrolina, Pernambuco, PE, Brazil. Tel./fax: +55 8738621711.

E-mail address: heribert@cpatsa.embrapa.br (A.H. de Castro Teixeira).
} 
respectively. Simplified parameterizations on roughness and evaporation resistances were performed. It could be concluded that net radiation can be estimated by means of a linear expression with incident global solar radiation depending on the type of vegetation. The variability of aerodynamic resistance $\left(r_{\mathrm{a}}\right)$ could be mainly explained by the friction velocity $\left(u_{*}\right)$ which on turn depends on the surface roughness length for momentum transport $\left(z_{O m}\right)$. The experimental data showed that for sparse canopies $z_{0 m}$ being $9 \%$ of the mean vegetation height is a doable operational rule for the semi-arid region of São Francisco River basin. The seasonal values of $r_{\mathrm{s}}$ for irrigated crops were highly correlated with water vapour pressure deficit. The availability of analytical methods to assess $r_{\mathrm{a}}$ and $r_{\mathrm{s}}$ makes the one-step Penman-Monteith equation suitable for the computation of actual evapotranspiration and water productivity analyses.

(c) 2008 Elsevier B.V. All rights reserved.

\section{Introduction}

The São Francisco River traverses six Brazilian states, comprising a total area of $640,000 \mathrm{~km}^{2}$. From this total, roughly 340,000 ha are irrigated, representing about $10 \%$ of the total São Francisco basin arable land. Fifty two percent of the basin area is located in the semi-arid zone in north-eastern Brazil, which is characterized by four-month rainy season (from January to April) with a rainfall ranging from 350 to $800 \mathrm{~mm} \mathrm{y}^{-1}$. The region produces high quality fruits like grapes and mangoes. Water managers in this semi-arid zone are faced with several challenges, such as increasing water resources scarcity, competition among different water user groups, over-exploitation of aquifers, climate and land use changes, non-source pollution, erosion, and sedimentation. Water policy makers have to work out strategies for integrated water management, which rely on a proper knowledge of the physical conditions of the river basins.

The basin water depletion is caused mainly by actual evapotranspiration $\left(E T_{\mathrm{a}}\right)$ from a range of crops and natural vegetation types, soil, build-up areas and water bodies. A proper knowledge of $E T_{\mathrm{a}}$ for various land covers is essential for managing scarce water resources and for keeping longterm evapotranspiration in balance with precipitation. Experimentally, $E T_{\mathrm{a}}$ can be determined by using weighing lysimeters, eddy covariance technique and the Bowen Ratio energy balance method. The use of lysimeters for trees is often not recommended, due to the development of the root systems. $E T_{\mathrm{a}}$ in irrigated crops and natural vegetation can be determined by analyzing the available energy at the land surfaces, the relevant potential differences (gradients of air temperature or air specific humidity), and the aerodynamic and bulk surface resistances (e.g. Gash and Shuttleworth, 2007). Examples of energy balance measurements by means of the Bowen ratio method above vegetated surfaces can be found in for instance Heilman et al. (1994, 1996). Eddy correlation technique is considered to be a standard procedure for determining the latent heat flux $(\lambda E)$ in field conditions (e.g. Oliver and Sene, 1992; Lund and Soegaard, 2003), albeit this method is not free from errors.

The commonly used Penman-Monteith equation is an appropriate mathematical framework to compute $E T_{\mathrm{a}}$ at local and regional scales (e.g Dolman, 1992; Riddersma and De Ridder, 1996; Bastiaanssen and Bandara, 2001). Despite that an extensive literature describes the theoretical mecha- nisms of turbulent transport above and within crop canopies; fewer studies have examined the actual soilvegetation-atmosphere-transfer parameters within landscapes of irrigated crops being interchanged with semi-arid natural land cover. Some earlier examples of evapotranspiration research in composite arid zone landscape are provided by for instance Kustas et al. (1994) for Walnut Gulch in Arizona, Chehbouni et al. (2001) for Mexico and Kite and Droogers (2000) for Turkey.

The objectives of the research described in this paper are (i) to review and improve parameterizations of the radiation and energy balances in irrigated crops and natural vegetation using field measurements, (ii) to predict $24 \mathrm{~h}$ net radiation and latent heat flux from instantaneous values and (iii) to determine the evaporation resistances $-r_{\mathrm{a}}$ and $r_{\mathrm{s}}$ - from irrigated crops (vineyards and mango orchard) and natural vegetation (caatinga).

\section{Vegetation types investigated}

\section{Wine grape}

The wine grape investigated was from Vitivinícola Santa Maria farm near the town of Lagoa Grande (Lat. $09^{\circ} 02^{\prime} \mathrm{S}$; Long. $40^{\circ} 11^{\prime} \mathrm{W}$ ), in Pernambuco state. The cultivar was Petite Syrah, 11 years old at the start of the experiments in 2002. The plants were spaced at $1.20 \mathrm{~m} \times 3.50 \mathrm{~m}$, trained vertically to a bilateral cordon and spur pruned. The cordon wire was at a height of $1.6 \mathrm{~m}$ with no foliage wires (a sprawl type canopy developed). There was no cover crop between the rows, and they were oriented in a north-south direction. The shoots were allowed to grow freely over the wires.

The daily drip irrigated area of 4.13 ha was bordered on all sides by other wine grapes. There was one drip emitter between two plants in the rows at a discharge rate of $4 \mathrm{~L} \mathrm{~h}^{-1}$, suspended on the wire. Although it is common in many wine production areas not to irrigate vines at budbreak, or shortly thereafter, the irrigation started soon after pruning without quantifying the water demand. The soil is sandy with a water retention capacity that increases with depth, presenting a cracked rock layer below $60 \mathrm{~cm}$ evidenced at the time of installation of the tensiometers.

The study involved two growing seasons during this year. The duration of the first growing season (GS1) was 132 days, elapsing from 7 February to 19 June 2002, while the second growing season (GS2) comprised 136 days, from 08 July to 22 
November 2002. Grapes were picked to produce wine from both periods.

\section{Table grape}

The table grape plot was located in the Vale das Uvas farm near the town of Petrolina (Lat. $09^{\circ} 18^{\prime} \mathrm{S}$; Long. $40^{\circ} 22^{\prime} \mathrm{W}$ ), Pernambuco state. The cultivar was Superior Seedless and the vineyard was only 2 years old during the first growing season. The plants were spaced at $3.5 \mathrm{~m} \times 4.0 \mathrm{~m}$, with the rows also oriented in the north-south direction. The vineyard had an overhead horizontal trellis system at $1.80 \mathrm{~m}$ height. The cover crop consisted of a mixture of legumes and grasses, and was incorporated into the soil after budbreak.

The plot investigated was $5.13 \mathrm{ha}$, surrounded by other table grapes. The grapes were daily micro sprinkler irrigated, with one in-line micro sprinkler between two vines on the ground at a discharge rate of $44 \mathrm{~L} \mathrm{~h}^{-1}$ which wetted $70 \%$ of the soil surface. As in wine grape, the farmer started the irrigation soon after pruning with large amount of water, thereby promoting high rates of direct soil water evaporation and cover crop transpiration at initial stages. The soil is also sandy throughout the vertical profile, but its water retention capacity does not increase with depth. Water holding capacity is higher in the upper soil layer $(0-20 \mathrm{~cm})$ due to high organic matter content.

The measurements involved two growing seasons (GS1 and GS2), during the same period but in different years: both from 08 July to 07 October, in 2002 and in 2003, because the crop was left resting between the two growing seasons, to avoid possible direct damage in fruits and high incidence of fungi diseases due to rainfall. The plants were not girdled nor sprayed with gibberellic acid and the leaves were not removed from fruit zone. At the stage of vegetative growth, non-fruitful shoots and lateral shoots growing in the fruiting zone were removed and at fruit growth stage the berries were protected with a white cover from direct solar radiation.

\section{Mango orchard}

The experiments with mango orchard were carried out from 2003 to 2005 in Fruitfort farm, Petrolina (Lat. 09²2' S, Long. $\left.40^{\circ} 34^{\prime} \mathrm{W}\right)$, Pernambuco state, Brazil. The cultivar was Tommy Atkins, 18 years old (in 2003), spaced in a regular square pattern at $10 \mathrm{~m} \times 10 \mathrm{~m}$, with an average height of $5.5 \mathrm{~m}$, mean leaf area index (LAl) of 5.6 and daily micro sprinkler irrigated in an area of $11.92 \mathrm{ha}$, with one in-line micro sprinkler between two trees on the ground at a discharge rate of $44 \mathrm{~L} \mathrm{~h}^{-1}$ wetting $70 \%$ of the soil surface. The irrigation requirements were calculated based on reference evapotranspiration and crop coefficients adjusted by crop stage. The orchard was bordered on all sides by other mango crops which similar height. There was no cover crop in the sandy soil witch has low water retention capacity.

Mango is a perennial crop. The study comprised two growing seasons. The duration of the first period was 390 days, from 01 October 2003 to 24 October 2004. The measurements continued into a second period of 370 days, elapsing from 25 November 2004 to 29 November 2005. For the two growing seasons, the growth cycle extended from November to October. The fruit trees undergo vegetative growth between November and January, followed by branch development from January to May. The mango trees flowered from May to July, with fruit initiation between June and July. Fruit growth occurred in July to August. Fruit maturation was during August and September. The fruits were picked in the period between September and October. The trees required some pruning during the crop development.

\section{Natural vegetation}

Caatinga is a vegetation type which location is mainly the Brazilian northeast. The flux tower was installed at $09^{\circ} 03^{\prime}$ $S$ and $40^{\circ} 19^{\prime} \mathrm{W}$, near the town of Lagoa Grande, Pernambuco state. The data comprised two years of measurements (2004 and 2005). This natural vegetation is a mixture of species and the more frequent are Caesalpinia microphylla Mart., Manihot pseudoglaziovii Pax et. K Hoffman, Croton conduplicatus Kunth and Sapium lanceolatum. The mean height of the mixed species in the site was $8 \mathrm{~m}$. Caatinga is defined by bush aspects possessing small leaves or thorns. These are some of the solutions found by the plants to avoid the loss of water by the epidermis. Besides some species have a loss of leaves in the dry season and some species store water. The vegetation is distributed in an irregular way, inhabiting contrasting areas similar to forests, with soil patches of bare soil and clumps of vegetation interspersed.

\section{Data collection}

The Bowen ratio surface energy balance method was used to measure the partition of net available energy into sensible and latent heat fluxes in vineyards. The sensors were installed at the centre of the plots. The gradients of air temperature and vapour pressure above the crops were calculated by using wet and dry thermocouples of cupper/ constantan at 0.5 and $1.5 \mathrm{~m}$ above the canopies.

In wine grape, the surface albedo $\left(\alpha_{0}=R_{\mathrm{R}} / R_{\mathrm{G}}\right)$ was measured through incident $\left(R_{\mathrm{G}}\right)$ and reflected $\left(R_{\mathrm{R}}\right)$ global solar radiation acquired with pyranometers faced up and down (model Eppley, number 19579, Rhode Island, USA). The net radiation $\left(R_{\mathrm{n}}\right)$ was measured at $1 \mathrm{~m}$ over the canopy with two net radiometers (model NR-Lite, Kipp \& Zonnen, Delft, the Netherlands), each one installed above a row of plants. The soil heat flux $(G)$ was obtained with four heat flux plates (HFT3-L, REBS, Radiation and Energy Balance Systems, Seattle, WA and Hukseflux, Delft, the Netherlands) at $2 \mathrm{~cm}$ soil depth and $0.5 \mathrm{~m}$ from the plants. $G$ was not corrected for the heat storage above the plates; however as the surface above $2 \mathrm{~cm}$ is very thin, it was assumed that these corrections could be neglected. Wind speed was measured with anemometers (R.M., Young wind Sentry, 03101, Michigan, USA) at two levels, i.e. 1.0 and $2.0 \mathrm{~m}$ above the canopy. Air temperature and relative humidity at $0.5 \mathrm{~m}$ near the leaves were obtained with a probe from Vaisala (model HMP 35A, Helsinki, Finland) at the same height of the first thermocouple. Soil moisture $(\theta)$ profiles were weekly monitored with tensiometers located between the drip emitters and the vine trunks in two rows. The sampling depths were 20,40 and $60 \mathrm{~cm}$ considered to represent the effective root zone for vineyards in local soil and cultural conditions. 
The same method, measurement procedures and equipment's manufacturers as for wine grapes were set up for table grapes with few differences. Only one net radiometer was installed above a row of plants. Two soil heat flux plates (model HFT3-L, REBS, Radiation and Energy Balance Systems, Seattle, WA) were used. As for table grapes, it was also assumed that corrections for $G$ due to the heat storage above the plates could be neglected. Air temperature and relative humidity near the leaves was measured by a probe (SKH 2013, Sky instruments LTD, Llandrindod Wells, UK) $0.5 \mathrm{~m}$ below the trellis system and only one anemometer was installed at $1.0 \mathrm{~m}$ above the canopy. $\theta$ profiles were also weekly monitored with tensiometers located between the micro sprinklers and the vine trunks along two rows at same soil depths as for wine grapes.

During the experiments in mango orchard, the eddy covariance (EC) method was applied. The system, installed at the centre of the plot, determined the sensible $(H)$ and latent heat fluxes $(\lambda E)$ by a three-axis sonic anemometer (Model CSAT3, Campbell Scientific, Logan, UT) and a krypton hygrometer (Model KH20, Campbell Scientific, Logan, UT), respectively, connected to a datalogger (Model CR10X, Campbell Scientific, Logan, UT, USA). The sensors were set at $3 \mathrm{~m}$ above the crown of a mango tree with a sampling frequency of $16 \mathrm{~Hz}$. The net radiation $\left(R_{\mathrm{n}}\right)$ was acquired with one net radiometer (model NR-Lite, Kipp \& Zonnen, Delft, The Netherlands) above a row of plants at a height of $2.5 \mathrm{~m}$ above the canopy. At this same height the surface albedo was measured with pyranometers faced up and down (model Eppley, number 19579, Rhode Island, USA). The soil heat flux $(G)$ was acquired with two heat flux plates (model HFT3-L, REBS, Radiation and Energy Balance Systems, Seattle, WA) at $2 \mathrm{~cm}$ soil depth and below the projected tree crown at $1 \mathrm{~m}$ from the trunk. As for vineyards, it was also assumed that corrections for $G$ due to the heat storage above the plates could be neglected. Air temperature and relative humidity near the leaves was measured with a probe (SKH 2013, Sky instruments LTD, Llandrindod Wells, UK) installed at the same height of the radiation sensors. $\theta$ profiles were weekly monitored with tensiometers located between the micro sprinklers and the mango trees. The sampling depths were $20,40,60,80,100$ and $120 \mathrm{~cm}$ considered to represent the effective root zone for mango orchards in local soil and cultural conditions.

All low frequency automatic measurements in irrigated crops were taken at each $5 \mathrm{~s}$ interval and averages of 10 min were stored in a datalogger of the same manufacturer as for the eddy covariance system in mango orchard.

The EC system over caatinga was installed at $11 \mathrm{~m}$ height above the ground, and consisted of a sonic anemometer from the same manufacturer as in mango orchard and a gas analyser (LI7500, LI-COR, Lincoln, Nebraska, USA) with the same sampling frequency and datalogger as for mango orchard. All components of short and long wave solar radiation were measured with pyranometers and pyrgeometers facing up and down (Kipp \& Zonnen, Delft, The Netherlands) at a height of $10 \mathrm{~m}$ from the ground. $R_{\mathrm{n}}$ was acquired at the same height of the other radiation sensors and $G$ was measured with one flux plate at $2 \mathrm{~cm}$ soil depth. As for irrigated crops, it was also assumed that corrections for $G$ due to the heat storage above the plates could be neglected. Both, the net radiometer and the flux plate were from the same man- ufacturer as in mango orchard. Microclimatic measurements of air temperature and relative humidity were taken above the vegetation with a probe from Vaisala (model HMP 45C-L, Helsinki, Finland) at the same height of the radiation sensors. The low frequency data in caatinga were collected each minute and $10 \mathrm{~min}$ averages were stored in the datalogger (CR23X, Campbell Scientific, Logan, UT, USA).

\section{Theory}

The overall calculations of radiation and energy balances are described in many text books. First the components of net radiation will be discussed, as $R_{\mathrm{n}}$ is the main supplier of energy required to drive the evapotranspiration process. The longwave radiation received from the atmosphere $\left(R_{\mathrm{L} \downarrow}\right)$ can be computed from the Stephan Boltzmann equation for all cases with direct measurements of air temperature $\left(T_{\mathrm{a}}\right)$, provided that the apparent emissivity of the atmosphere $\left(\varepsilon_{\mathrm{a}}\right)$ is known. Various empirical solutions exist to describe $\varepsilon_{\mathrm{a}}$ (Brunt, 1939; Swinbank, 1963). During a comparative study executed by the University of Idaho (Allen et al., 2000), the empirical equation developed by Bastiaanssen (1995) appeared to perform most favourably, provided that it is calibrated against local observations (see also Allen et al., 2007). Thus:

$\varepsilon_{\mathrm{a}}=a\left(-\ln \tau_{\mathrm{sw}}\right)^{b}$

where $\tau_{\mathrm{sw}}$ is the shortwave atmospheric transmissivity and $a$ and $b$ are regression coefficients.

All radiation components of the caatinga site were measured, which made it feasible to isolate $\varepsilon_{\mathrm{a}}$ from measured $R_{\mathrm{L} \downarrow}$ and $T_{\mathrm{a}}$ values. The $a$ and $b$ coefficients of Eq. (1) could be calibrated and this equation was applied to retrieve $\varepsilon_{\mathrm{a}}$ and $R_{\mathrm{L} \downarrow}$ in the irrigated sites. The incoming longwave radiation $\left(R_{\mathrm{L} \downarrow}\right)$ could be computed from the Stephan Boltzmann equation for all irrigated crops, after making the proper correction for atmospheric emissivity:

$R_{\mathrm{L} \downarrow}=\varepsilon_{\mathrm{a}} \sigma T_{\mathrm{a}}^{4}$

where $\sigma\left(5.67 \times 10^{-8} \mathrm{~W} \mathrm{~m}^{-2} \mathrm{~K}^{-4}\right)$ is the Stefan-Boltzmann constant and $T_{\mathrm{a}}(\mathrm{K})$ the air temperature.

Values of surface albedo $\left(\alpha_{0}\right.$ were obtained by measuring from incoming global solar radiation $R_{\mathrm{G}}$ and outgoing solar radiation $R_{\mathrm{R}}$ in wine grape, mango orchard and caatinga. For table grape $R_{\mathrm{R}}$ was estimated from the regression equation between net short wave radiation $\left(R_{\mathrm{G}}-R\right.$ R) and $R_{\mathrm{n}}$ developed by Azevedo et al. (1997) for the same crop in semi-arid conditions of São Francisco River basin.

Using the $24 \mathrm{~h}$ values of short wave components $\left(R_{\mathrm{G}}-\right.$ $R_{\mathrm{R}}$ ), $R_{\mathrm{n}}$ and $R_{\mathrm{L} \downarrow}$ the $24 \mathrm{~h}$ values of $R_{\mathrm{L} \uparrow}$ could be estimated as a residual in radiation balance for irrigated fruit crops where this radiation parameter was not measured.

The $24 \mathrm{~h}$ values of the net radiation $\left(R_{\mathrm{n}_{24}}\right)$ can be described by the $24 \mathrm{~h}$ values of shortwave component, with a correction term for net longwave radiation at the same time scale. De Bruin (1987) and de Bruin and Stricker (2000) reported on the use of the following equation:

$R_{\mathrm{n}_{24}}=\left(1-\alpha_{0_{24}}\right) R_{G_{24}}-a \tau_{\mathrm{sw}_{24}}$

where $a$ is a regression coefficient of relationship between net long wave radiation $\left(R_{\mathrm{nl}_{24}}\right)$ and atmospheric transmissivity $\left(\tau_{\mathrm{sw}_{24}}\right)$ at daily scale. 
Eq. (3) has the advantage that the emissivities during daytime and night time necessary for solving the Stephan Boltzmann equation can be omitted. Thus, $R_{\mathrm{n}_{24}}$ can be quantified if net shortwave radiation is measured and the adjusting factor, $a$, is known.

The Penman-Monteith equation was developed to predict evapotranspiration from vegetated surfaces (Allen et al., 1998):

$\lambda E=\frac{\Delta\left(R_{\mathrm{n}}-G_{0}\right)+\rho_{\mathrm{a}} C_{\mathrm{p}} D / r_{\mathrm{a}}}{\Delta+\gamma\left(1+r_{\mathrm{s}} / r_{\mathrm{a}}\right)}$

where $\Delta\left(\mathrm{kPa}^{\circ} \mathrm{C}^{-1}\right)$ is the slope of the saturated vapour pressure curve, $\rho_{\mathrm{a}}\left(\mathrm{kg} \mathrm{m}^{-3}\right)$ is the air density, $c_{\mathrm{p}}\left(\mathrm{J} \mathrm{kg}^{-1} \mathrm{~K}^{-1}\right)$ is the air specific heat at constant pressure, $D(\mathrm{kPa})$ is the vapour pressure deficit and $\gamma\left(\mathrm{kPa}^{\circ} \mathrm{C}^{-1}\right)$ is the psychometric constant.

The evaporative fraction describes the complex energy partitioning process by single parameters:

$E_{\mathrm{F}}=\lambda E /\left(R_{\mathrm{n}}-G\right)$

The advantage is the simplicity and that $E_{\mathrm{F}}$ describes whether soils are dry or wet. Very wet vegetated soils tend to $E_{\mathrm{F}}$ becoming 1.0 and very dry soils to $E_{\mathrm{F}}$ being approximately zero.

The drag force between land and atmosphere in the Penman-Monteith equation is accounted for the aerodynamic resistance $\left(r_{\mathrm{a}}\right)$, and this parameter requires the surface roughness conditions $z_{O h}$ and friction velocities $u_{*}$ to be specified:

$r_{\mathrm{a}}=\frac{\ln \left[\frac{z-d}{z_{0 h}}\right]}{k u_{*}}-\psi_{h}\left(\frac{z-d}{L}\right)$

where $z_{0 h}(m)$ is the roughness length governing transfer of heat and vapour away from the land surface into the atmosphere, $k$ is the von Karman's constant $(0.41), u_{*}\left(\mathrm{~m} \mathrm{~s}^{-1}\right)$ is the friction velocity, $z(\mathrm{~m})$ is the measurement height, $d$ $(\mathrm{m})$ is the displacement height, $\psi_{h}$ is the stability correction due to buoyancy and $L$ is the Obukhov length. In vineyards $L$ was obtained by an iterative numerical method starting with a value of $10^{6} \mathrm{~m}$, while for mango orchard and natural vegetation it was derived from eddy covariance measurements.

For vineyards the friction velocity was calculated using flux profile relationships $\left(u_{\mathrm{FP} *}\right)$ with two-level near-ground wind speed measurements:

$u_{\mathrm{FP} *}=\frac{k\left(u_{2}-u_{1}\right)}{\ln \left[\frac{z_{2}-d}{z_{1}-d}\right]-\psi_{\mathrm{m}}\left(\frac{z_{2}-d}{L}\right)+\psi_{\mathrm{m}}\left(\frac{z_{1}-d}{L}\right)}$

where $u_{1}$ and $u_{2}$ are the wind speed values at heights $z_{1}$ and $z_{2}(2.6 \mathrm{~m}$ and $3.6 \mathrm{~m}$ for wine grape and $2.8 \mathrm{~m}$ and $3.8 \mathrm{~m}$ for table grape).

In the case of table grape, the wind speed measurements $u_{2}$ at $z_{2}(3.8 \mathrm{~m})$ were absent; only air temperature $\left(T_{\mathrm{a}}\right)$ was measured at this height. The wind speed values for this level were estimated by means of the $H$ calculations, the vertical air temperature increments $\Delta T$ between $z_{1}$ and $z_{2}$ and the $r_{a}$ values. Initially, a neutral condition in the logarithm wind profile equation was used to derive the first value of $u_{*}$, which could be subsequently improved with $L$.
The eddy covariance data of mango orchard and caatinga could be used to acquire the friction velocity $\left(u_{\mathrm{EC} *}\right)$ directly without wind speed measurements at multiple heights:

$U_{\mathrm{EC} *}=\sqrt{-\overline{W^{\prime} U^{\prime}}}$

where $u^{\prime}$ and $w^{\prime}$ are instantaneous departures from the average horizontal $(u)$ and vertical $(w)$ wind speed measured by the sonic anemometers. The roughness length for moment transfer was obtained from either $u_{\mathrm{FP} *}$ or $u_{\mathrm{EC} *}$ as

$Z_{0 m}=\frac{z-d}{\exp \left(\frac{k u(z)}{u_{\mathrm{FP}, E C_{*}}}+\Psi_{m}\left(\frac{\mathrm{z}-d}{L}\right)\right)}$

where $u(z)$ is the wind speed at the first level $\left(z=z_{1}\right)$ in vineyards or at the height of the sonic anemometer in mango orchard or caatinga.

Ratios of $d / h_{\mathrm{v}}$ were usually reported to lie in the range of 0.6 (Garrat, 1978), although several authors assumed (Hicks, 1973) or calculated (Riou et al., 1987) a negligible $d$ for extensive vineyards. We considered $d=0.66 h_{\mathrm{v}}$ (Allen et al., 1998) and solve $z_{O m}$ as the unknown in Eq. (9). Early measurements in closed canopies reported $z_{0 m}=0.13 h_{v}$, (e.g. Monteith, 1973). The roughness parameters for vegetation under incomplete canopy cover were less and the $z_{0 m} / h_{v}$ relationship seems to vary more than for closed canopies (e.g. Hicks, 1973; Garrat, 1978; Riou et al. 1987). Garrat (1978) found $z_{0 \mathrm{~m}} / h_{\mathrm{v}}$ of 0.05 for a natural savannah; Driese and Reiners (1997) reported averaged $z_{0 m} / h_{v}$ values of $0.04,0.04$ and 0.13 for natural sagebrush, saltbush and greasewood, respectively. Van Dijk et al. (2004) found a value of $z_{0 m} / h_{v}=0.03$ for a rain fed cropping system with maize and cassava. Originally the relationship between $z_{O h}$ and $z_{O m}$ was denoted by the dimensionless quantity $\mathrm{kB}^{-1}$ :

$\mathrm{kB}^{-1}=\ln \left(\mathrm{Z}_{\text {om }} / \mathrm{Z}_{\text {oh }}\right)$

In many hydro-meteorological models containing a submodel for the vegetation-atmosphere interaction, the results of Thom (1972) and Garrat and Hicks (1973) are used and $\mathrm{kB}^{-1}$ for vegetation is taken as a constant at about 2.0. Following them and also the standard work of Allen et al. (1998), we assume a kB-1 value of 2.3 , being equivalent to $z_{O h}=0.1 z_{O m}$.

The surface resistance parameters in the Penman-Monteith equation are combined into one parameter, the 'bulk' surface resistance $\left(r_{\mathrm{s}}\right)$ which operates in series with the aerodynamic resistance $\left(r_{\mathrm{a}}\right)$. Microclimatic data of air temperature and relative humidity were used together $R_{\mathrm{n}}, \lambda E$ and $G$ to estimate $r_{\mathrm{s}}$ inverting Eq. (4). The effects of $D$ and $\theta$ in the $r_{\mathrm{s}}$ values of irrigated fruit crops and natural vegetation growing in semi-arid conditions of São Francisco River basin were evaluated and specific relationships were found.

\section{Results and discussion}

\section{Energy fluxes and their parameterizations}

\section{Radiation balance}

The daily values of the radiation balances are presented in Table $1 . R_{\mathrm{n}}$ averaged $46 \%$ of $R_{\mathrm{G}}$ for wine grape, $55 \%$ for table grape, $51 \%$ for mango orchard, and $53 \%$ for caatinga. The rule of thumb of $R_{\mathrm{n}}$ being approximately $50 \%$ of $R_{\mathrm{G}}$ (e.g. 
Table 1 Daily averages of the radiation balance for irrigated crops (Wine Grape - WG, Table Grape - TG, Mango orchard - MG) for the first (GS1) and second (GS2) growing seasons and for natural vegetation (Caatinga - CT) for two years (2004 and 2005): global solar radiation $\left(R_{\mathrm{G}}\right)$, reflected solar radiation $\left(R_{\mathrm{R}}\right)$, incident longwave radiation $\left(R_{\mathrm{L} \downarrow}\right)$, emitted longwave radiation $\left(R_{\mathrm{L} \uparrow}\right)$, and ratio of reflected solar radiation $\left(R_{\mathrm{R}} / R_{\mathrm{G}}\right)$ and net radiation $\left(R_{\mathrm{n}} / R_{\mathrm{G}}\right)$ to global solar radiation

\begin{tabular}{lllllll}
\hline Vegetation/period & $R_{\mathrm{G}}\left(\mathrm{MJ} \mathrm{m}^{-2} \mathrm{~d}^{-1}\right)$ & $R_{\mathrm{R}}\left(\mathrm{MJ} \mathrm{m}^{-2} \mathrm{~d}^{-1}\right)$ & $R_{\mathrm{L} \downarrow}\left(\mathrm{MJ} \mathrm{m}^{-2} \mathrm{~d}^{-1}\right)$ & $R_{\mathrm{L} \uparrow}\left(\mathrm{MJ} \mathrm{m}^{-2} \mathrm{~d}^{-1}\right)$ & $R_{\mathrm{R}} / R_{\mathrm{G}}(-)$ & $R_{\mathrm{n}} / R_{\mathrm{G}}(-)$ \\
\hline WG_GS1 & 20.10 & 4.20 & 34.56 & 40.69 & 0.21 & 0.48 \\
WG_GS2 & 23.87 & 5.15 & 32.95 & 41.36 & 0.22 & 0.43 \\
TG_GS1 & 20.96 & 3.85 & 32.37 & 37.88 & 0.18 & 0.55 \\
TG_GS2 & 20.49 & 3.83 & 32.57 & 38.27 & 0.19 & 0.54 \\
MG_GS1 & 21.19 & 3.29 & 34.09 & 41.42 & 0.16 & 0.50 \\
MG_GS2 & 21.92 & 3.30 & 33.97 & 41.50 & 0.15 & 0.51 \\
CT_2004 & 21.60 & 3.08 & 33.51 & 40.47 & 0.14 & 0.54 \\
CT_2005 & 20.84 & 2.70 & 34.16 & 41.52 & 0.13 & 0.52 \\
\hline
\end{tabular}

Makkink, 1957; Oliver and Sene, 1992) was herewith confirmed to be a realistic first estimate.

For all sites, there was a consistent relationship between the half hourly values of $R_{\mathrm{n}}$ and $R_{\mathrm{G}}$ (Fig. 1). The slopes of all equations ranged between 0.60 and 0.75 , and were similar to those obtained by Oliver and Sene (1992) for a rainfed vineyard in Spain, as well as for mature Sultana grapes, growing in a T-trellis system (Yunusa et al., 2004) and other ecosystems in Australia (Hughes et al., 2001). The high correlations imply that $R_{\mathrm{n}}$ can be estimated from $R_{\mathrm{G}}$ only. This is relevant because net radiometers are only occasionally available; sometimes there are technical problems associ- ated with the sensors during some periods of an experiment. The spatial variation of $R_{\mathrm{G}}$ across vast river basins can nowadays be well described from satellites by means of cloud cover data, which aids the description of the spatial variation of $R_{\mathrm{n}}$.

The relationship between $R_{\mathrm{G}}$ and $R_{\mathrm{n}}$ is, to a large extent, affected by the surface albedo $\left(\alpha_{0}\right)$. The seasonal behaviour of $\alpha_{0}$ is shown in Fig. 2 for all vegetation types studied. The oscillation in daily averaged values is mainly due to the crop stages, cultural practices and irrigation for irrigated crops and rainfall regime in natural vegetation. The cover crop in table grape caused high $\alpha_{0}$ values before bud break. After

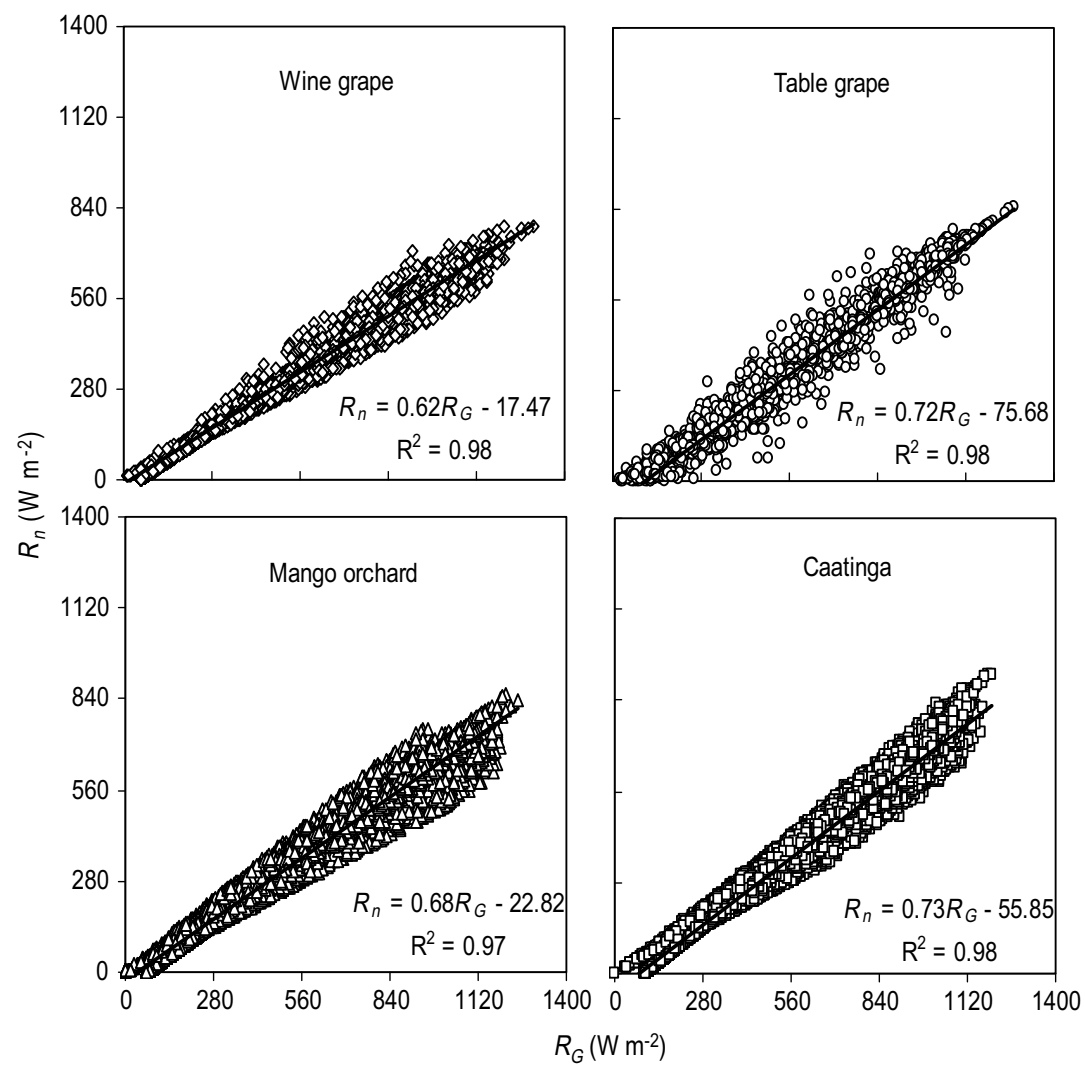

Figure 1 Relationship between net radiation $\left(R_{\mathrm{n}}\right)$ and global solar radiation $\left(R_{\mathrm{G}}\right)$ for 30 min time intervals during daylight hours for irrigated fruit crops (wine grape, table grape and mango orchard) and natural vegetation (Caatinga). 


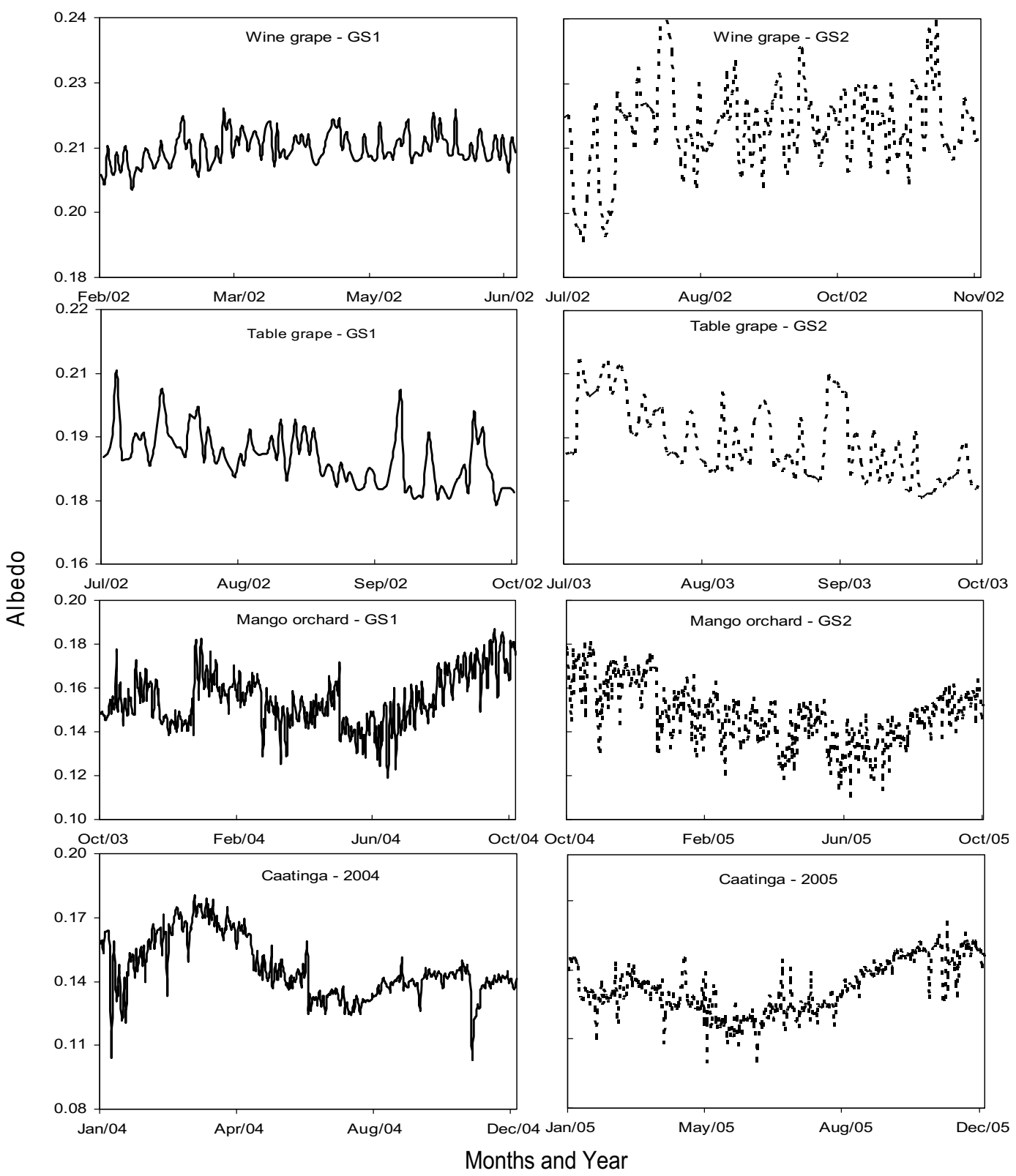

Figure 2 Seasonal variation of the surface albedo for the first (GS1) and second (GS2) growing seasons of irrigated crops: (a) and (b) - wine grape; (c) and (d) - table grape; (e) and (f) - mango orchard and (g) and natural vegetation (h) - Caatinga.

this stage $\alpha_{0}$ varied due to several cultural practices reaching the lower values at the senescence stage. Differences between the seasonal $\alpha_{0}$ of wine and table grapes were further due to the different trellis systems and cultural management. Mango trees displayed variation in $\alpha_{0}$ according to their phenological stages and time of the year. However, more variation occurred during the rainy season when leaves were alternatively wet and dry due to interception. Higher values occurred as the leaf area increased under these conditions. This is a normal feature (Oliver and Sene, 1992).

The variability of $\alpha_{0}$ in caatinga can be mainly attributed to variation in surface moisture conditions due to rainfall. The amounts of rainfall were 720 and $340 \mathrm{~mm}$ for 2004 and 2005 respectively, concentrated from January to April. The long term average rainfall is about $570 \mathrm{~mm} \mathrm{yr}^{-1}$. Monteith and Unsworth (1990) reported $\alpha_{0}$ values between 0.15 and 0.26 for natural vegetation, higher than those for caatinga, possibly because of different surface moisture conditions and background reflectivity. However, the caatinga values were similar to those $(0.12-0.13)$ reported for tropical rain forest (Oguntoyinbo, 1970; Pinker et al., 1980; Shuttleworth, 1988). The modification of $\alpha_{0}$ with moisture conditions is in agreement with several authors (Campbell and Norman, 1998; Lobell and Asner, 2002; Van Dijk et al., 2004; Li et al., 2006).

$R_{\mathrm{R}}$ represented on average $22 \%$ of $R_{\mathrm{G}}$ for wine grape, $19 \%$ for table grape, $16 \%$ for mango orchard and $14 \%$ for 


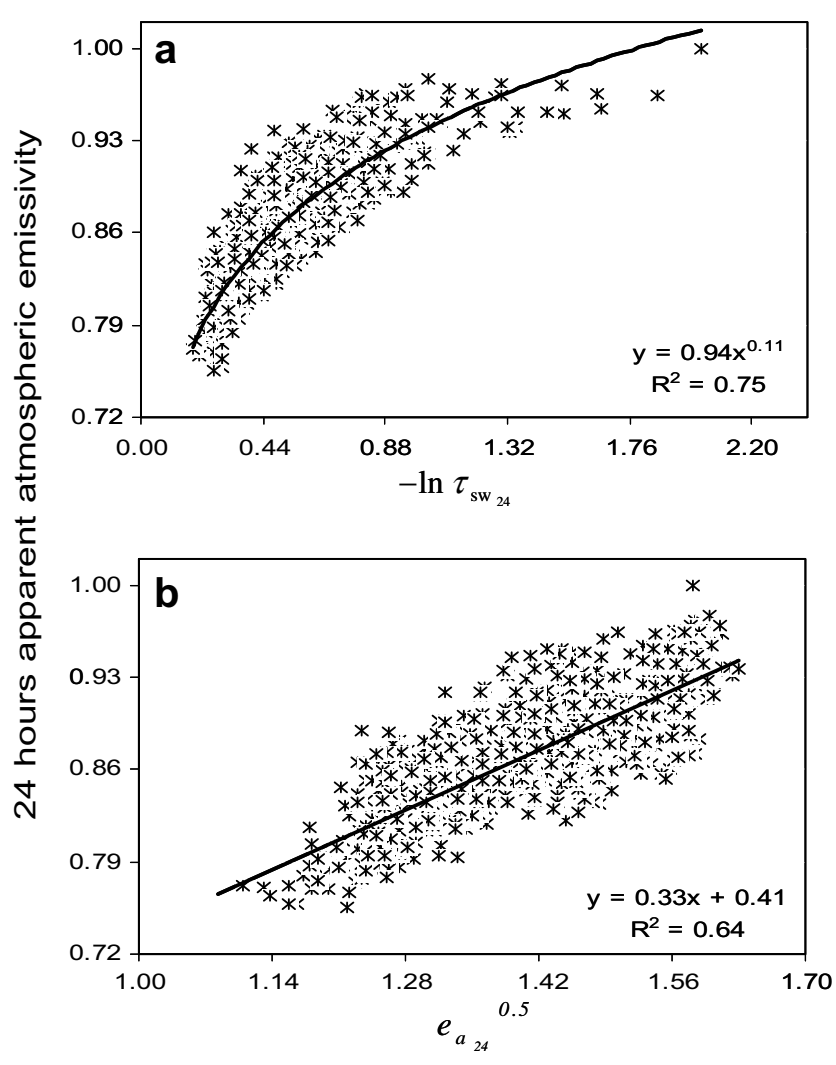

Figure 3 Relationships between apparent atmospheric emissivity with atmospheric transmissivity (a) and with actual air vapour pressure (b) for $24 \mathrm{~h}$ time scale.

caatinga, respectively (Table 1). Wine grape was the highest reflector out of the four agro-ecosystems investigated. This can be explained by the use of the vertical trellis system together with the exposure of the brightly reflecting soils to $R_{\mathrm{G}}$. More oscillation in values during GS2 of wine grape could be attributed to the sun position and cloud free conditions in the second half of the year. The averaged albedo data for all vegetation of the current study were smaller than for those found in a rainfed vineyard $(0.27)$ by Oliver and Sene (1992) on whitish calcareous soils.

The longwave radiation measurements over caatinga made it possible to estimate the $24 \mathrm{~h}$ apparent atmospheric emissivity $\left(\varepsilon_{\mathrm{a}}\right)$, which was in turn related to atmospheric transmissivity $-\tau_{\mathrm{sw}}$ (Eq. (1)) as well as to actual vapour pressure $-e_{\mathrm{a}}$ (Fig. $3 \mathrm{a}$ and $\mathrm{b}$ ). The last relation followed the classical parameterization that is commonly applied for irrigated crops (Allen et al., 1998). The relationship with $\tau_{\mathrm{sw}}$ appeared to be better $\left(R^{2}=0.75\right)$ than for $e_{\mathrm{a}}\left(R^{2}=0.64\right)$. This is probably because the first parameter describes the overall conditions in the atmospheric column, rather than those at one given level near to the surface. The coefficients found for Eq. (1) $(a=0.94 ; b=0.11)$ are in between the values obtained for Idaho $(a=0.85$ and $b=0.09$; Allen et al., 2000) and Egypt ( $a=1.08$ and $b=0.26$; Bastiaanssen, 1995). The availability of $\varepsilon_{\mathrm{a}}$ made it feasible to compute $R_{\mathrm{L} \downarrow}$ at daily time scale.

Eq. (3) was tested because it allows the extrapolation of instantaneous to daily values of net radiation $\left(R_{\mathrm{n}_{24}}\right)$. Fig. 4 shows that the fundamental basis of describing $R_{\mathrm{n}_{24}}$ by means $\tau_{\mathrm{sw}_{24}}$ is valid; the overall agreement $\left(R^{2}=0.78-\right.$
0.83 ) is acceptable for semi-arid conditions of the São Francisco basin. The $R_{\mathrm{n}_{24}}$ coefficient for all agro-ecosystems appears to be $a=143$. In a grassland catchments area in the Netherlands, de Bruin and Stricker (2000) used $a=135$, while the original value was $a=110$. The difference can be ascribed to differences in macroclimatic conditions.

\section{Energy balance}

Average daily values of the energy balances for entire growing seasons for irrigated crops and for two years in natural vegetation are summarized in Table 2 . Near neutral atmospheric conditions predominated above the irrigated crops with the sensible heat flux $(H)$ accounting for $13-20 \%$ of $R_{\mathrm{n}}$. Most of $R_{\mathrm{n}}$ was partitioned into latent heat flux $(\lambda E)$, averaging, $79 \%$, $89 \%$, and $77 \%$, for wine grape, table grape and mango orchard, respectively. The correspondent values of the evaporative fraction $\left(E_{\mathrm{F}}\right)$ ranged from 0.73 to 0.89 . Not surprisingly, the intensively irrigated table grapes exhibited the highest $\lambda E$ and $E_{\mathrm{F}}$ values.

Due to the vertical trellis system that resulted in more exposed soil between the rows, lower values of $E_{\mathrm{F}}$ were found for wine grape than for table grape. The experiments in wine grape involved growing seasons with different solar angles. The $24 \mathrm{~h}$ averaged value of $G$ in wine grape was negative for the first half of the year, while during the second half $G$ was positive. This indicates heating of the ground during the second growing season, as a result of the apparent movement of the sun associated to the vertical trellis system (see Table 2). Changes from negative to positive values of $G$ were also reported by Li et al. (2006) for the steppe of Mongolia, when seasonal energy partition was analyzed. Differences in the partition of the energy balance with different trellis and crop-training systems in vineyards were also reported by Novello et al. (1992), Heilman et al. (1996) and Rana et al. (2004).

While the values of $\lambda E$ for mango orchard exceeded those for wine grapes (not for table grapes), the $E_{\mathrm{F}}$ values were lower. These differences could be ascribed to the lower $\alpha_{0}$ of mango that resulted in greater $R_{\mathrm{n}}$ values. For both seasons of table grape and mango orchard $G$ was negative, while for natural vegetation for both years it was nearly zero. Negative values indicated that the ground was an energy source to the atmosphere.

The caatinga natural ecosystem characteristics were manifested in low values of both $E_{\mathrm{F}}$ and $\lambda E$ rates. Despite the relatively high values for $R_{\mathrm{n}}$, the $\lambda E$ was low implying in a greater part of available energy being partitioned as $H$. During the dry season, the air above caatinga received more heat than water vapour, resulting to warmer air layers. During the rainy seasons, $R_{\mathrm{n}}$ was essentially converted into $\lambda E$, however these periods were short and for the annual scale, $H$ exceeded $\lambda E$.

A classical problem in energy balance modelling is the conversion from instantaneous components of this balance to daily values. The most common procedure is to compute instantaneous $E_{\mathrm{F}}$, and consequently apply the same value for the entire day (e.g. Brutsaert and Sugita (1992), Bastiaanssen (1995), Su (2002) and Wang et al. (2007)). Literature on temporal variation of $E_{\mathrm{F}}$ has reported that the constantvalue approach has an acceptable accuracy (e.g. Crago (1996)). Farah and Bastiaanssen (2004) demonstrated that there could be a deviation on a particular day, but that it 


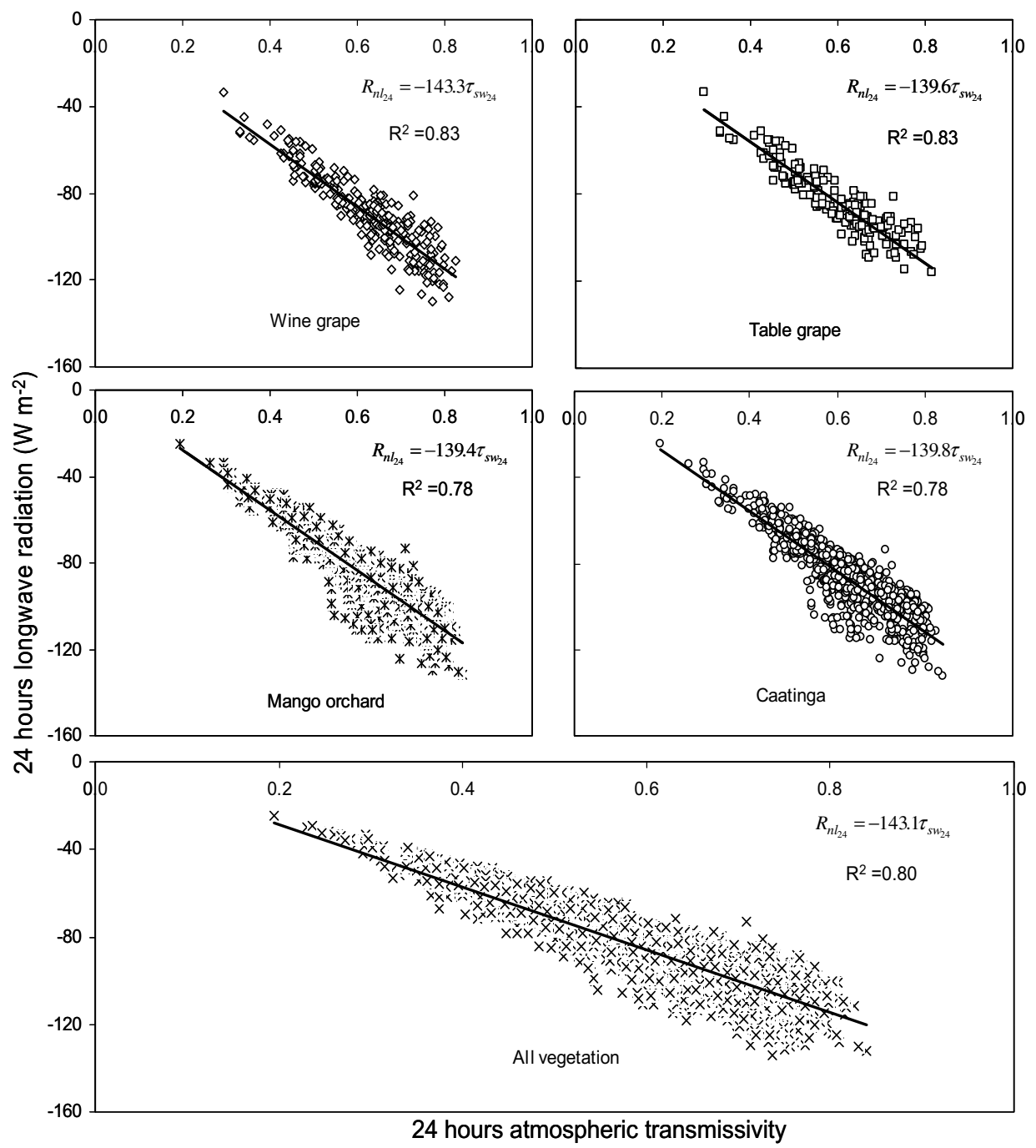

Figure 4 Relationships between net long wave radiation $\left(R_{\mathrm{nl}_{24}}\right)$ and atmospheric transmissivity $\tau_{24}$ on a $24 \mathrm{~h}$ basis. The value of the vertical axis expresses the a-coefficient of Eq. (4).

Table 2 Averaged daily ( $24 \mathrm{~h}$ ) energy balance for irrigated crops (Wine Grape - WG, Table Grape - TG, Mango orchard - MG) for the first (GS1) and second (GS2) growing seasons and for natural vegetation (Caatinga - CT) for two years (2004 and 2005): net radiation $\left(R_{\mathrm{n}}\right)$, latent heat flux $(\lambda E)$, sensible heat flux $(H)$, soil heat flux $(G)$ and evaporative fraction $\left(E_{\mathrm{F}}=\lambda E /\left(R_{\mathrm{n}}-G\right)\right)$

\begin{tabular}{lcccrc}
\hline Vegetation/period & $R_{\mathrm{n}}\left(\mathrm{MJ} \mathrm{m}^{-2} \mathrm{~d}^{-1}\right)$ & $\lambda E\left(\mathrm{MJ} \mathrm{m}^{-2} \mathrm{~d}^{-1}\right)$ & $H\left(\mathrm{MJ} \mathrm{m}^{-2} \mathrm{~d}^{-1}\right)$ & $G\left(\mathrm{MJ} \mathrm{m}^{-2} \mathrm{~d}^{-1}\right)$ & $E_{\mathrm{F}}(-)$ \\
\hline WG_GS1 & 9.77 & 8.07 & 1.90 & -0.20 & 0.81 \\
WG_GS2 & 10.31 & 7.73 & 2.08 & 0.50 & 0.79 \\
TG_GS1 & 11.60 & 10.57 & 1.32 & -0.29 & 0.89 \\
TG_GS2 & 10.96 & 9.46 & 1.58 & -0.08 & 0.86 \\
MG_GS1 & 10.58 & 8.45 & 1.38 & -0.37 & 0.77 \\
MG_GS2 & 11.09 & 4.62 & 1.72 & -0.18 & 0.73 \\
CT_2004 & 11.56 & 2.67 & 6.69 & 0.03 & 0.40 \\
CT_2005 & 10.78 & 6.88 & 0.03 & 0.25 \\
\hline
\end{tabular}

can be used to acquire $E T_{\text {a }}$ on weekly to monthly time scales.

The seasonal variations of $E_{\mathrm{F}}$ together the precipitations are shown in Fig. 5. During the growing seasons, vineyards were daily irrigated resulting to fairly constant values of
$E_{\mathrm{F}}$ as they were cultivated in periods with absence or low amounts of rains. In mango orchard the high values of $E_{\mathrm{F}}$ after the rains are evident as the growing seasons were longer involving the rainy periods. The natural vegetation has the ability to respond quickly to rainfall causing the values 


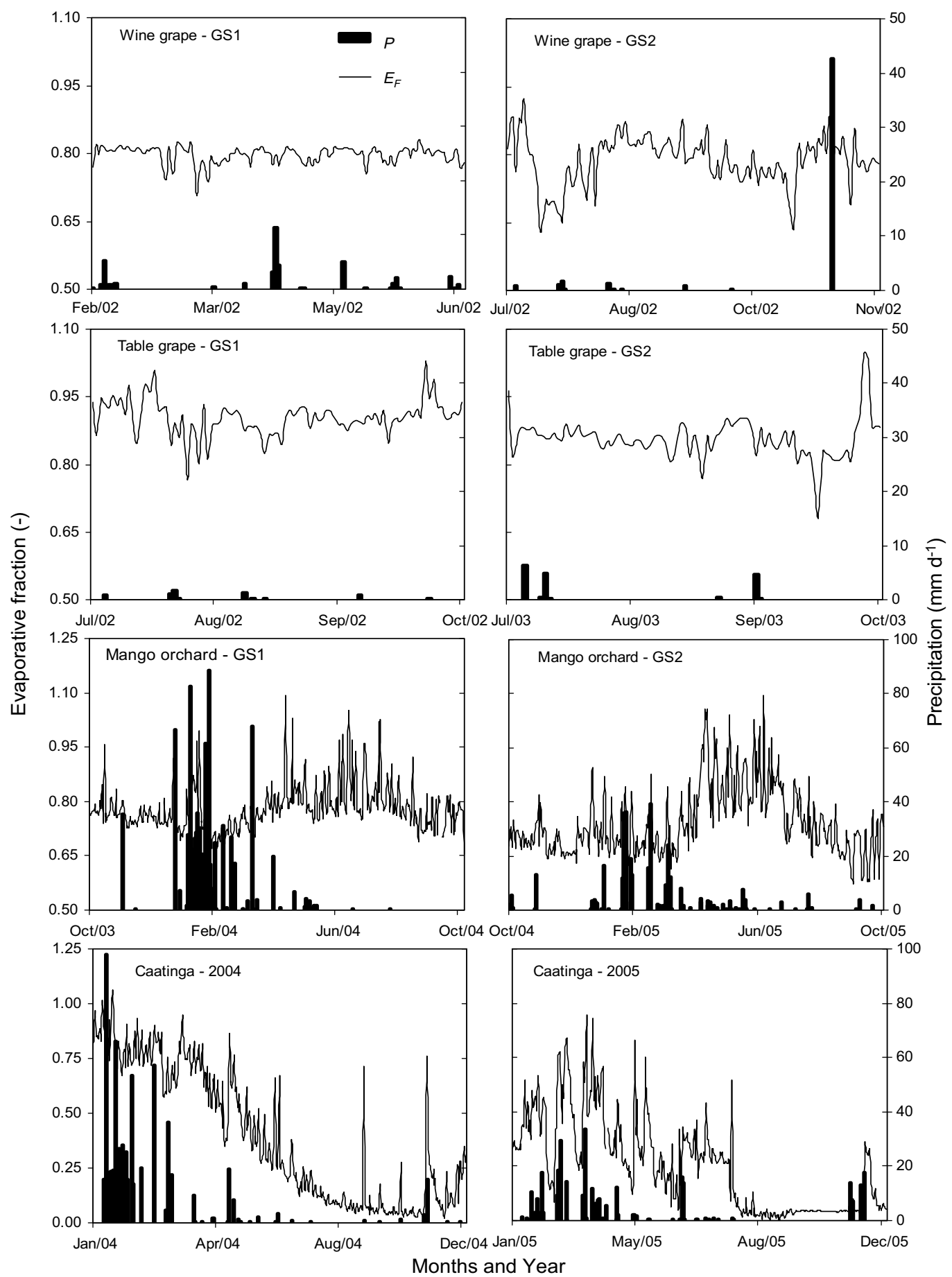

Figure 5 Seasonal variation of the evaporative fraction $\left(E_{\mathrm{F}}\right)$ and precipitation $(P)$ for irrigated crops (Wine grape, table grape and mango orchard) and natural vegetation (caatinga).

of $E_{\mathrm{F}}$ high soon after the rains. The biggest effect was during 2004, when unusual precipitation occurred from January to April.

The $24 \mathrm{~h}\left(E_{F_{24}}\right)$ and daylight $\left(E_{F_{\text {daylight }}}\right)$ values of evaporative fraction were calculated with the averaged values of $R_{\mathrm{n}}, \lambda E$ and $G$ for these time scales fulfilling $R_{\mathrm{n}}>0$ for daylight conditions. For midday $\left(E_{F_{12}}\right)$, the instantaneous values at $12.00 \mathrm{~h}$ were considered (Fig. 6). The scatter in the graph with $E_{F_{12}}$ is larger than for $E_{F_{\text {daylight }}}$, because the latter repre- sents a time integrated value that to a large extent affects the $E_{F_{24}}$. Yet, the values of $E_{F_{24}}$ are higher than those for $E_{F_{\text {dayight }}}$ for mango and caatinga. While for these two last vegetation a correction is necessary to acquire $E_{F_{24}}$ from $E_{F_{12}}$, for vineyards this is not. The implication is that $E_{\mathrm{F}}$ constancy varies with agricultural and natural ecosystems is an important finding for energy balance models at different time scales. Values of $\lambda E_{\text {night }}$ from eddy correlation measurements (mango orchard and caatinga) were higher than those 

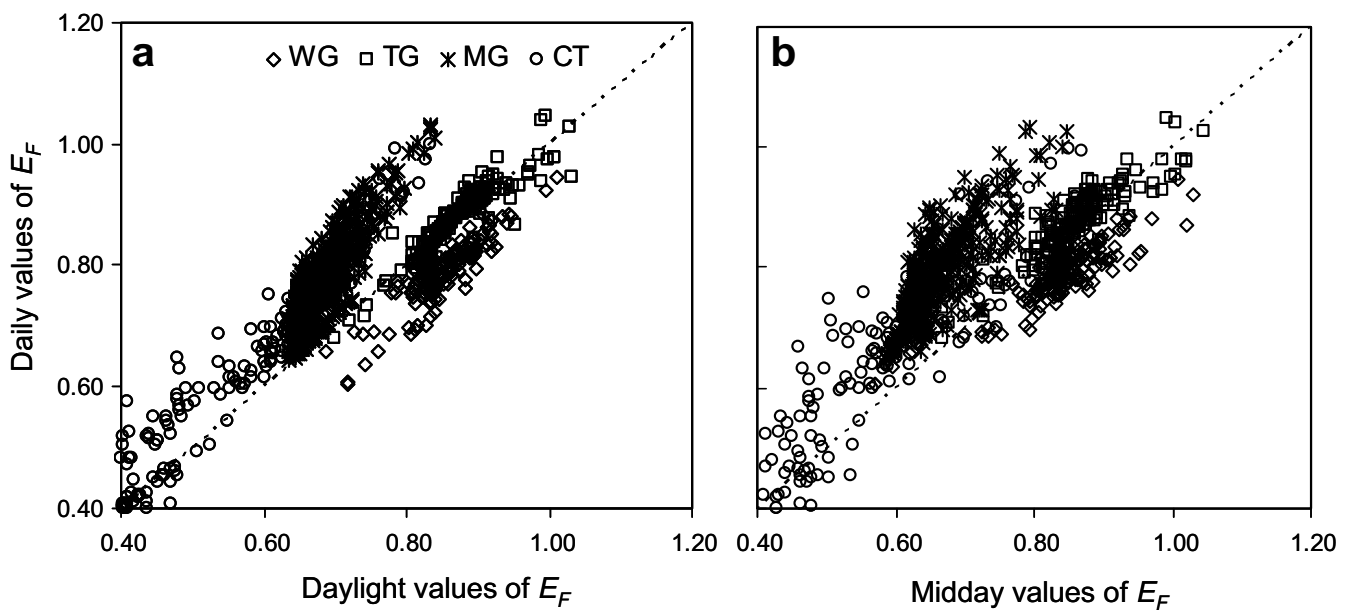

Figure 6 Relationships between the values $E F_{24}$ Vs. $E F_{\text {daylight }}$ (a) and of $E F_{24}$ vs. the noon-time $E F_{12}$ values (b) for wine grape (WG), table grape (TG), mango orchard (MG), caatinga (CT) and for all these vegetation together.

from the Bowen ratio method (vineyards). This implies that grapes have more condensation than the first two types of vegetation. Whether this is a true observation or a consequence of the different micro-meteorological measurements has not been further investigated. The values of $\lambda E_{\text {night }}$ in mango orchard and caatinga contribute to a higher $E_{F_{24}}$.

\section{Soil-vegetation parameterizations}

\section{Momentum roughness parameters}

The seasonal (irrigated crops) and annual (natural vegetation) averaged measurements of the key vegetation parameters related to evapotranspiration are shown in Table 3.

Due to the tall and aerodynamically rough canopy architecture, mango orchard presented the greatest values of $u_{*}$. The averaged value was $0.49 \mathrm{~m} \mathrm{~s}^{-1}$, much greater than for wine grape $\left(0.21 \mathrm{~m} \mathrm{~s}^{-1}\right)$. The average $z_{O m}$ value for wine grape was $0.08 \mathrm{~m}$ and for table grape $0.24 \mathrm{~m}$. Sene (1994) reported values ranging from 0.04 to $0.06 \mathrm{~m}$ for rainfed wine grape growing under semi-arid conditions in Castilla
La Mancha with larger spacing within and between the rows $(5 \mathrm{~m} \times 5 \mathrm{~m})$. Van den Hurk et al. (1996) showed for the same region in Spain (but at a different plot) values from $0.01 \mathrm{~m}$ to $0.06 \mathrm{~m}$, varying proportionally to the leaf area index (LAI). The maximum value seems to be in good agreement with our wine grape results. Table grape has a rougher surface than wine grape, and thus a larger $z_{O m}$ that generates more turbulent movement above the canopy.

Although the mean value of $z_{O m}$ for table grape was higher than for wine grape, the variations along the growing seasons were lower. The standard deviation for $z_{0 m}$ was $0.04 \mathrm{~m}$ in wine grape vineyard and only $0.01 \mathrm{~m}$ in the table grape vineyard (Fig. 7). The vertical trellis system with a low LAI in wine grape showed results that depended on the wind direction. The rows of vineyards were north-eastern oriented. When the wind blew more parallel to the rows $\left(115^{\circ}\right) z_{\text {Om }}$ values were $50 \%$ of those when the wind direction was near south-east $\left(130^{\circ}\right)$. Table grape was insensitive to changes in wind direction (see Table 3). Hicks (1973) reported that the drag coefficient doubled as the wind direction swung from parallel to normal of the vine rows in

Table 3 Average values of the vegetation parameters of irrigated crops (Wine Grape - WG, Table Grape - TG, Mango orchard $M G$ ), for the first (GS1) and second (GS2) growing seasons and for natural vegetation (Caatinga - CT) for 2004 and 2005 : aerodynamic $\left(r_{\mathrm{a}}\right)$ and surface $\left(r_{\mathrm{s}}\right)$ resistances; friction velocity $\left(u_{*}\right)$; roughness lengths for momentum transfer $\left(z_{O m}\right)$; mean vegetation height $\left(h_{\mathrm{v}}\right)$; vapour pressure deficit $(D)$, wind speed above the canopies $(u)$ and wind direction (WD)

\begin{tabular}{lllllllll}
\hline Vegetation/period & $r_{\mathrm{a}}\left(\mathrm{s} \mathrm{m}^{-1}\right)$ & $r_{\mathrm{s}}\left(\mathrm{s} \mathrm{m}^{-1}\right)$ & $u_{*}\left(\mathrm{~m} \mathrm{~s}^{-1}\right)$ & $z_{O m}(\mathrm{~m})$ & $h_{\mathrm{v}}(\mathrm{m})$ & $D(\mathrm{kPa})$ & $u\left(\mathrm{~m} \mathrm{~s}^{-1}\right)$ & WD $($ Degrees $)$ \\
\hline WG_GS1 & 114 & 131 & 0.21 & 0.11 & 1.6 & 1.8 & 1.9 & 128 \\
WG_GS2 & 109 & 125 & 0.21 & 0.06 & 1.6 & 2.1 & 2.1 & 116 \\
TG_GS1 & 63 & 64 & 0.38 & 0.23 & 1.8 & 1.3 & 2.0 & 118 \\
TG_GS2 & 66 & 82 & 0.40 & 0.24 & 1.8 & 1.2 & 2.1 & 138 \\
MG_GS1 & 36 & 133 & 0.50 & 0.50 & 5.5 & 1.3 & 2.6 & 126 \\
MG_GS2 & 37 & 133 & 0.48 & 0.54 & 5.5 & 1.3 & 2.4 & 124 \\
CT_2004 & 53 & 1542 & 0.39 & 0.43 & 8.0 & 1.5 & 2.8 & 135 \\
CT_2005 & 58 & 2332 & 0.39 & 0.33 & 8.0 & 1.5 & 2.9 & 132 \\
\hline
\end{tabular}

The height of the anemometers was $1 \mathrm{~m}$ above the canopies of vineyards, while they were at $3 \mathrm{~m}$ above the canopies in mango orchard and caatinga. 


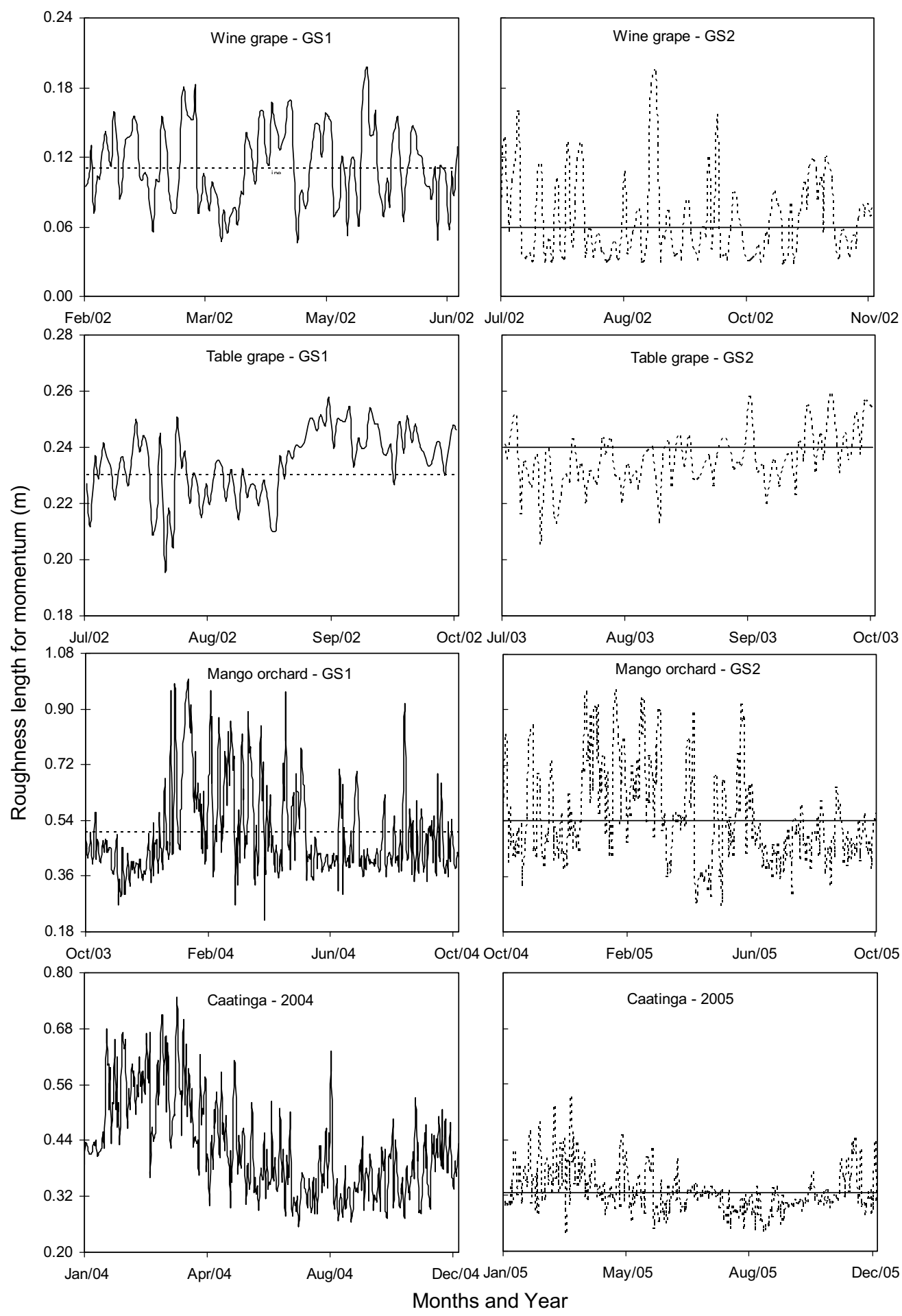

Figure 7 Seasonal variation of roughness length for momentum transfer $\left(z_{0 m}\right)$ for the first (GS1) and second (GS2) growing seasons of irrigated crops: (a) and (b) - wine grape; (c) and (d) - table grape; (e) and (f) - mango orchard and for 2004 and 2005 of natural vegetation: $(\mathrm{g})$ and $(\mathrm{h})$ - caatinga. Horizontal bars are averaged values.

vertical trellis. When they blew normal to the rows, $z_{O m}$ was found to be about $13 \%$ of the vineyard height, behaviour typical for rough and closed canopies. In the present study, the horizontal overhead trellis of table grape covered almost all the soil beneath the canopy few days after bud break creating a rougher surface.
The $z_{O m}$ values in the mango orchard averaged $0.52 \mathrm{~m}$. The big crowns of the trees enhanced the momentum flux. The higher values of wind speed $(u)$ above the canopy, if compared with vineyards, were due to the higher level of the anemometer. Despite the taller mixed species of caatinga $(8 \mathrm{~m})$ in relation to the trees of mango orchard 
$(5.5 \mathrm{~m})$, results showed lower aerodynamic roughness values of $z_{O m}(0.38 \mathrm{~m})$ and $u_{*}\left(0.39 \mathrm{~m} \mathrm{~s}^{-1}\right)$. The reason of these lower values can be explained by the patchwork of bushes and the irregular spacing among them. During an international land surface flux campaign on Sahelian bushland with irregular spacing among stripes of bushes, the values for $z_{0 m}$ were also found to be at the lower side $(0.22$ to $0.27 \mathrm{~m}$ : Troufleau et al., 1997).

The $z_{O m}$ values for mango orchard and for caatinga showed both effects from the rainy period (between January and March) which increases in leaf areas and thereby the surface roughness. More distinct differences in rough-

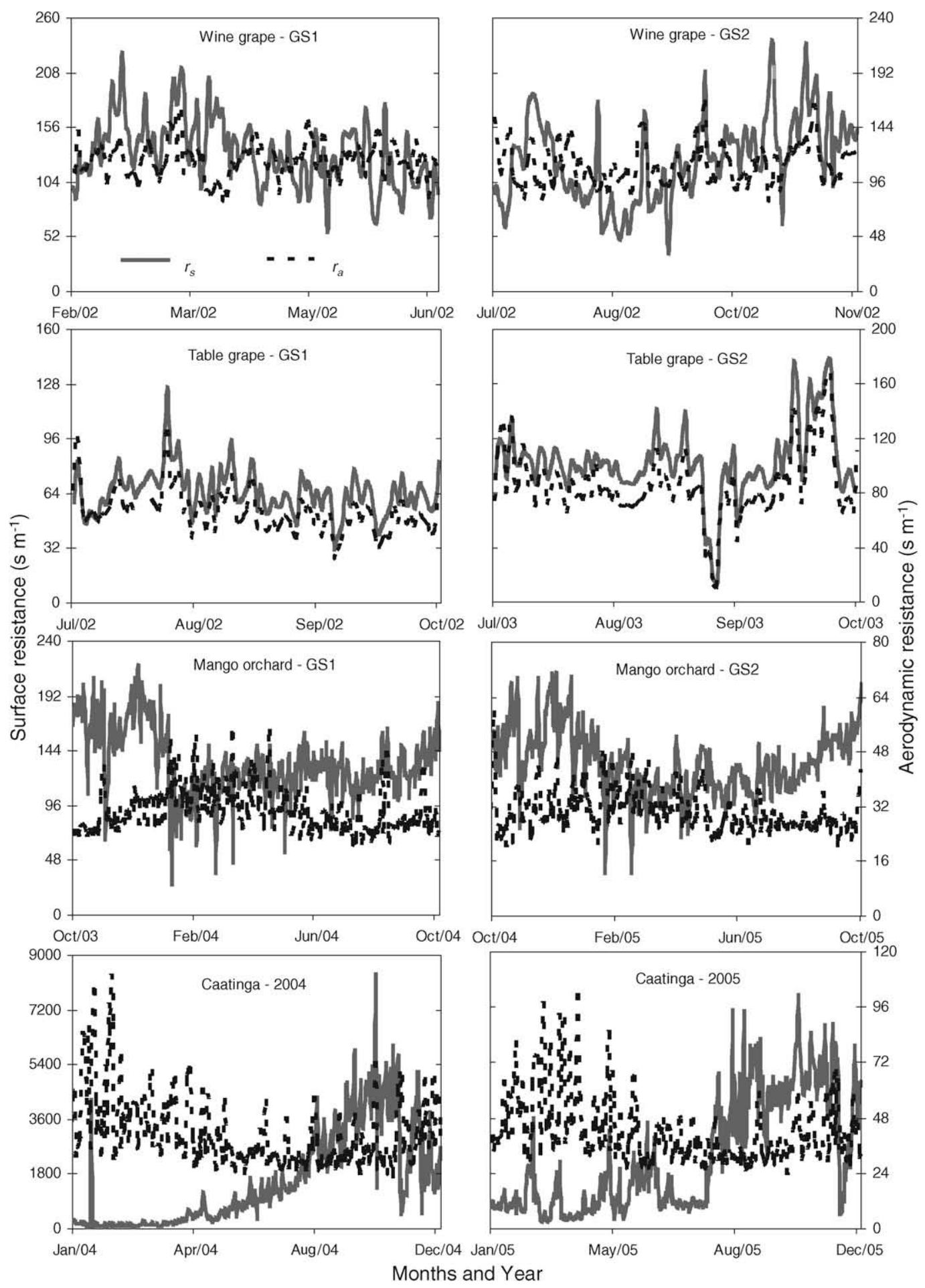

Figure 8 Seasonal variation of the bulk surface $\left(r_{\mathrm{s}}\right)$ and aerodynamic $\left(r_{\mathrm{a}}\right)$ resistances for the first (GS1) and second (GS2) growing seasons of irrigated crops: (a) and (b) - wine grape; (c) and (d) - table grape; (e) and (f) - mango orchard and for natural vegetation: $(\mathrm{g})$ and $(\mathrm{h})$ - caatinga. 
ness parameters for natural vegetation were visible during 2004 than in 2005 (Fig. 7). This is related to the unusual high rainfall amount in 2004.

According to Sene (1994), sparse crops typically present $z_{O m}$ values in the range $5-10 \%$ of the average vegetation height $\left(h_{\mathrm{v}}\right)$ while for uniform crops the values are typically about $13 \%$. With our averaged values of $z_{O m}$ of $0.06 h_{v}$ for wine grape, $0.13 h_{v}$ for table grape, $0.09 h_{v}$ for mango orchard and $0.05 h_{v}$ for caatinga, one can conclude that table grape is an exception due to its deviating canopy architecture. On average, $z_{0 m}$ is approximately $9 \%$ of the $h_{v}$.

\section{Aerodynamic and bulk surface resistances}

The seasonal-averaged values of resistances are shown in Table 3 while the seasonal variations are depicted in Fig. 8. Wine grape had the highest averaged value of $r_{\mathrm{a}}$ $\left(112 \mathrm{~s} \mathrm{~m}^{-1}\right)$, followed by table grape $\left(65 \mathrm{~s} \mathrm{~m}^{-1}\right)$, caatinga $\left(55 \mathrm{~s} \mathrm{~m}^{-1}\right)$ and mango orchard $\left(36 \mathrm{~s} \mathrm{~m}^{-1}\right)$. The low $r_{\mathrm{a}}$ for mango orchard is due to the aerodynamically rough canopy architecture evidenced by the highest values of $u_{*}$ and $z_{O m}$. Wine grape presented less oscillation than table grape, as a result of the progressive coverage of the soil caused by the overhead trellis system together with several cultural practices along the growing seasons in the second vineyard. In the case of mango orchard, more vegetative growth during the rainy period promoted higher values of $r_{\mathrm{a}}$ due the increase of leaf area and $z_{O m}$. For caatinga, this effect also occurred, but more accentuated.

The maximum values of $r_{\mathrm{s}}$ among the vegetation types studied were detected in caatinga (mean $r_{\mathrm{s}}$ is $1937 \mathrm{~s} \mathrm{~m}^{-1}$, see Table 3 ). The low moisture conditions during the dry season caused the stomata to close preventing the plant from cell moisture depletion and wilting. Wine grape and mango trees presented similar $r_{\mathrm{s}}$ values around $130 \mathrm{~s} \mathrm{~m}^{-1}$, while table grape $r_{\mathrm{s}}$ values were as low as $74 \mathrm{~s} \mathrm{~m}^{-1}$. Table grape has almost a double LAl compared to wine grape. The lower value of $D$ in micro sprinkler irrigation system also contributed to lower $r_{\mathrm{s}}$ values.

The daylight variation of $r_{\mathrm{s}}$ and $D$ are shown in Fig. 9. Low values during the early morning represented the dominance of energetically dependent physiological control over $\lambda E$. The greatest variation occurring at this time of the day is because $r_{\mathrm{s}}$ is close to its minimum value, partially due to dew (van Dijk et al., 2004). The low and near-minimum values for $r_{\mathrm{s}}$ only hold when all environmental conditions are optimal at the same time. Such pre-requisite does not last long, and a quick rise of $r_{\mathrm{s}}$ during morning hours is envisaged. The progressive soil moisture constraints and rising $T_{\mathrm{a}}$ and $D$ induce stomatal closure. The higher values of $r_{\mathrm{s}}$ during the late afternoon are mainly related to the constraints induced by high $T_{\mathrm{a}}$ and $D$, in conjunction with lower levels of $R_{\mathrm{G}}$. It is thus a combined effect, and no single responsible variable can be determined. The globally accepted standard ecological theories first presented by Jarvis (1976) and Stewart (1989) are herewith confirmed.

Fig. 9 suggests that the daylight behaviour of $r_{\mathrm{s}}=f(D)$ is most tight for caatinga. The likely reason for this is the control of $\theta$ on stomatal regulation. While the irrigated crops experience diurnal cycles in root zone water availability, caatinga responds stronger to rainfall regime. Baldochi et al. (2004) observed the same phenomena for an oak, grass and savannah landscape. The relationships between $r_{\mathrm{s}}$ and $D$ at a daily time scale throughout the measuring period are shown in Fig. 10. Except caatinga $\left(R^{2}=0.39\right)$, irri-
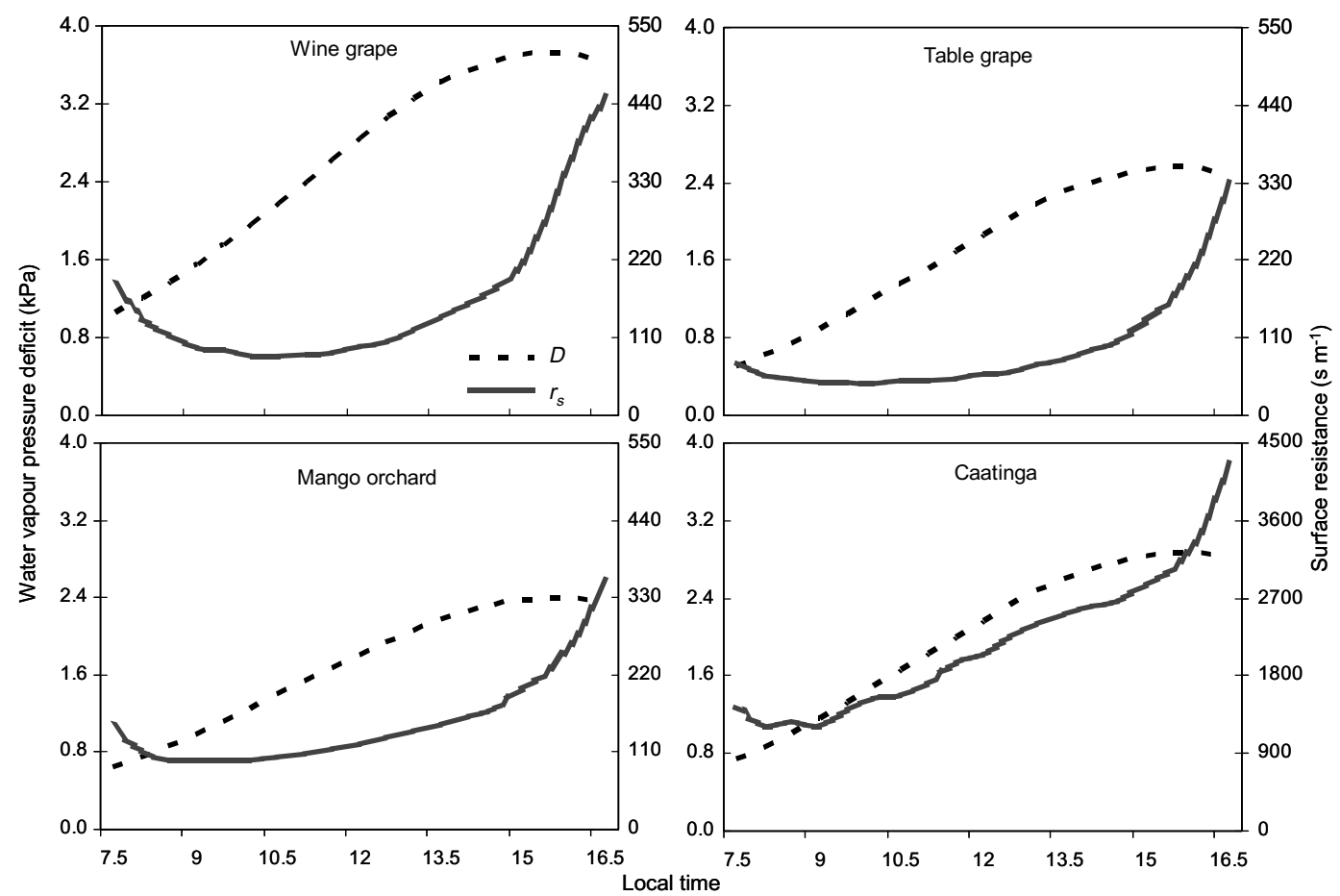

Figure 9 Daylight fluctuation of bulk surface resistances $-r_{s}$ and vapour pressure deficit $-D$ for irrigated crops (wine grape, table grapes and mango orchard) and natural vegetation (caatinga). 
A.H. de Castro Teixeira et al.

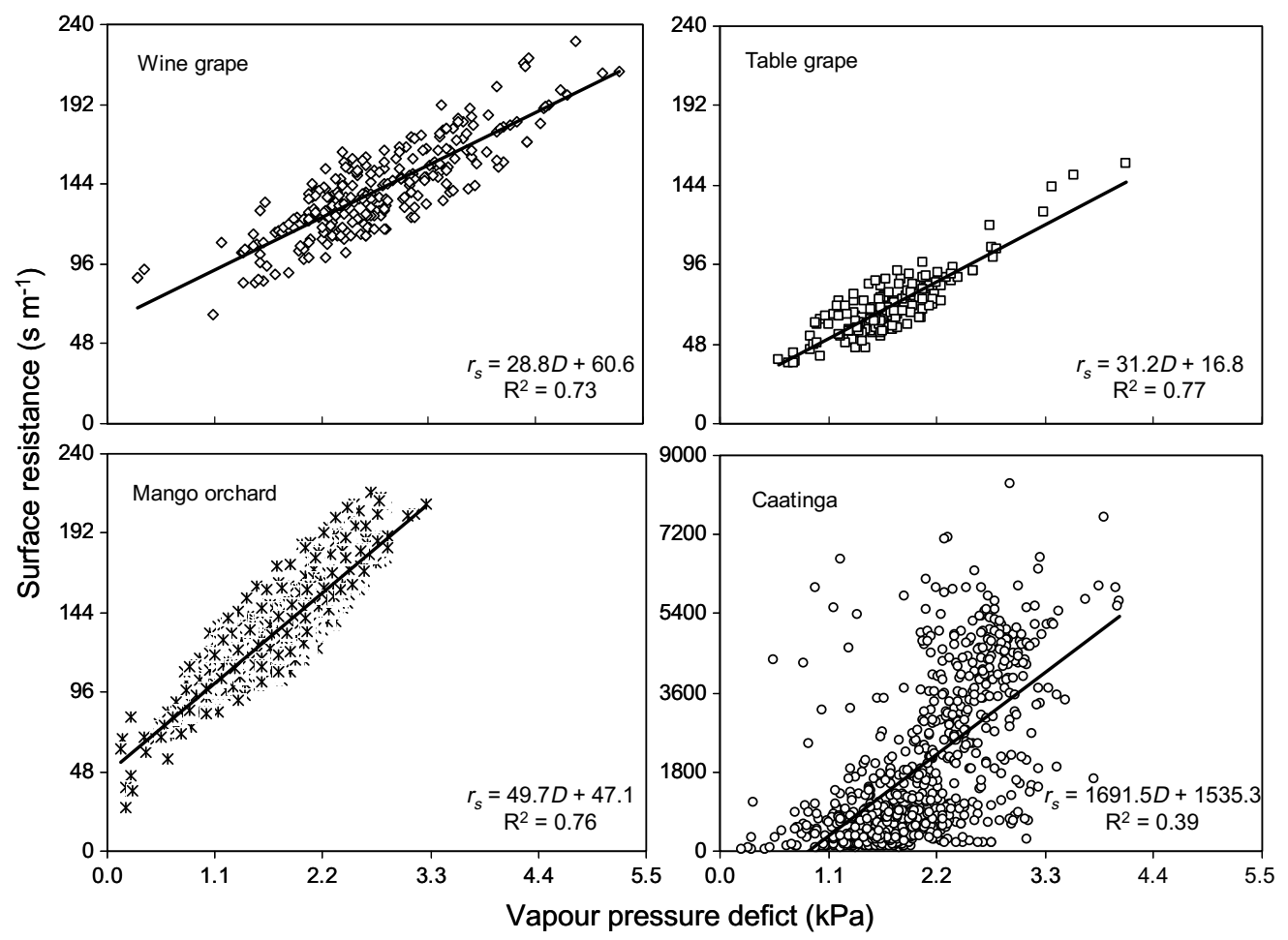

Figure 10 Daylight relationships between surface resistance $\left(r_{s}\right)$ and vapour pressure deficit $(D)$ for irrigated crops (Wine grape, table grapes and mango orchard) and natural vegetation (Caatinga).

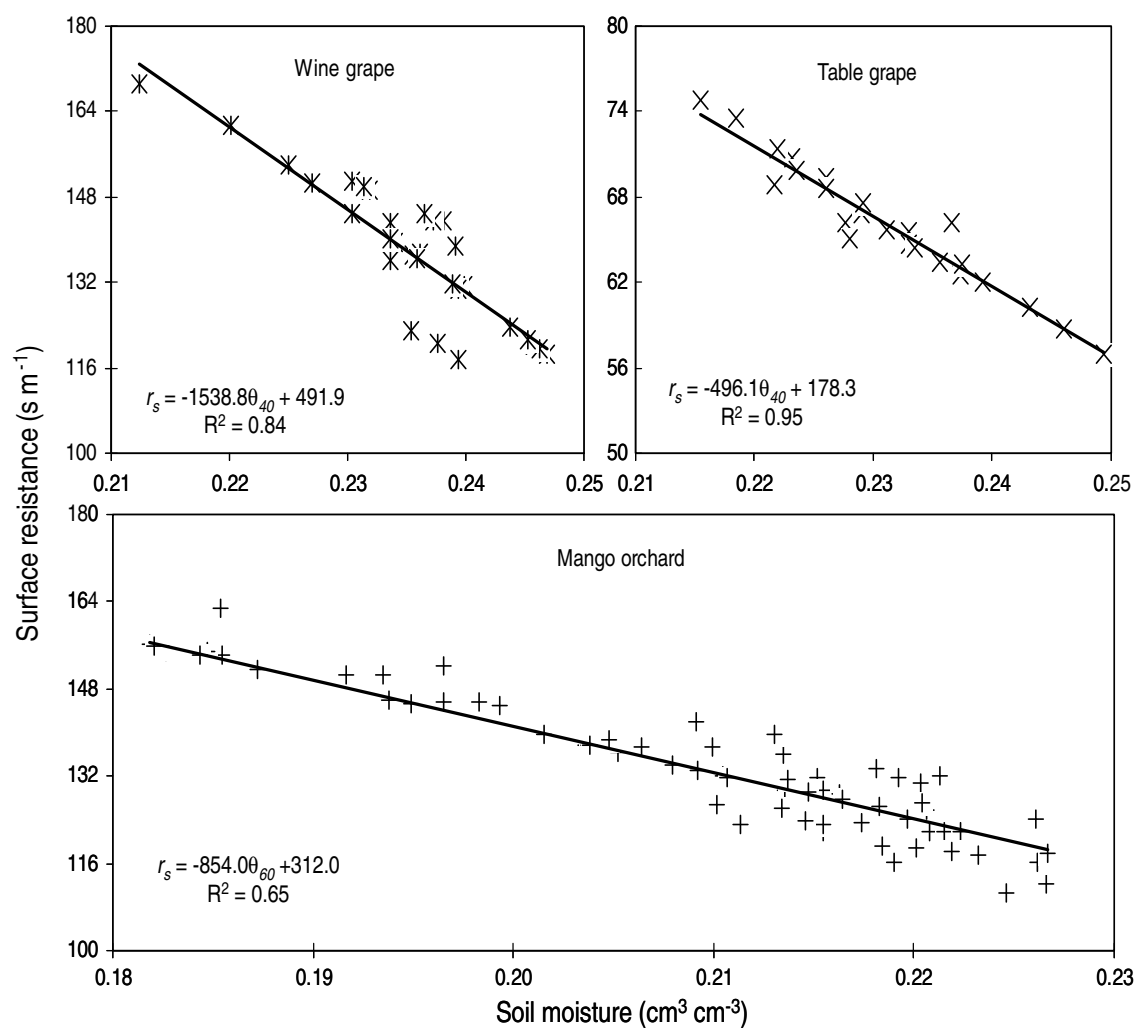

Figure 11 Weekly relationships between surface resistance $\left(r_{\mathrm{s}}\right)$ and soil moisture in irrigated vineyards for $40 \mathrm{~cm}$ soil depth $\left(\theta_{40}\right)$ and mango orchard for $60 \mathrm{~cm}$ soil depth $\left(\theta_{60}\right)$.

gated vineyards and mango showed a high correlation. While there were higher water vapour gradients between the sto- mata and the near-surface atmosphere in dry periods, these gradients at the same time induced partial stomatal 
closure. There is thus a negative feedback system in agroecosystems that dampens any significant variation in $\lambda E$.

The effect of $\theta$ on $r_{\mathrm{s}}$ is evident when studying their relationships for irrigated fruit crops (Fig. 11). While the $r_{\mathrm{s}}$ of caatinga was dominantly controlled by seasonal soil moisture variability, in irrigated fruit crops it was controlled by both $\theta\left(R^{2}=0.65-0.95\right)$ and $D\left(R^{2}=0.73-0.77\right)$. Mango was more responsive to $D\left(R^{2}=0.76\right)$ than to $\theta\left(R^{2}=0.65\right)$. Hence, $E T_{\mathrm{a}}$ and water productivity in this orchard are largely influenced by $D$ levels. The role of on-farm irrigation management in vineyards need thus to be done more alert than in mango orchards. One can practice very precise irrigation, but the water balance in mango orchards will be influenced by $D$.

The $r_{\mathrm{s}}$ response to $\theta$ was published for alfalfa by van Bavel (1967) and for wheat by Hatfield (1985). Larger changes of $r_{\mathrm{s}}$ occur at small changes in wet soils. At an average soil water content of $0.20 \mathrm{~cm}^{3} \mathrm{~cm}^{-3}$, the sensitivity of table grapes is $\mathrm{d} r_{s} / \mathrm{d} \theta=496$ for wine grapes, $\mathrm{d} r_{s} / \mathrm{d} \theta=1539$ for wine grape, $\mathrm{dr} r_{s} / \mathrm{d} \theta=853$ for mango orchard, $\mathrm{d} r_{s} / \mathrm{d} \theta=80$ for wheat (Hatfield, 1985) and $\mathrm{d} r_{s} / \mathrm{d} \theta=350$ for alfalfa (van Bavel, 1967). The highest slopes of $\mathrm{d} r_{s} / \mathrm{d} \theta$ reveal the strongest response to changes in available soil water. Wine grape thus exhibits the strongest response of $r_{\mathrm{s}}$ to minor changes of $\theta$, followed by mango, table grape, alfalfa and finally wheat.

\section{Conclusions}

The diurnal and seasonal variation of the radiation and energy balance components in irrigated crops and natural vegetation in the Brazilian semi arid region of Sao Francisco River basin have been investigated. These investigations allowed a better understanding of the energy fluxes and the physical vegetation properties that affect these exchange processes, what are important for appraising the impact of land use changes on the regional scale water balance. From radiation measurements, it could be concluded that net radiation can be estimated by means of a linear expression with global solar radiation depending on the type of vegetation. The presented equation to estimate apparent emissivity of the atmosphere from atmospheric transmissivity had a better correspondence with field measurements than the standardized FAO equation based in actual vapour pressure. The atmospheric emissivity estimation is fundamental for the estimation of instantaneous net radiation fluxes.

The daily values of evaporative fraction $\left(E_{\mathrm{F}}\right)$ for all irrigated crops varied between 0.71 (mango orchard) to 0.90 (table grape), revealing that most net available energy $\left(R_{\mathrm{n}}-G\right)$ is converted into actual evapotranspiration. This implies that the atmospheric boundary layer over wet irrigated perimeters receives small quantities of sensible heat, and stays thus relatively cold. The $E_{\mathrm{F}}$ values of caatinga, the natural vegetation, were in an annual scale with $0.25-0.40$ much smaller than for irrigated crops. A distinct seasonal variation of $E_{\mathrm{F}}$ in caatinga was found because of the water availability linked to precipitation patterns during the year.

It was demonstrated that daytime and daily energy balances can be estimated from instantaneous measurements, provided that net radiation and soil heat flux are known across time integrated periods. The energy balances for mango orchard and caatinga showed that a slight correction is required if the instantaneous $E_{\mathrm{F}}$ is to be used as a representative value for a $24 \mathrm{~h}$ period.

Parameterizations of the aerodynamic $\left(r_{\mathrm{a}}\right)$ and the bulk surface $\left(r_{\mathrm{s}}\right)$ resistances facilitated the analysis of the comprehensive evapotranspiration from heterogeneous land surfaces. The variability of $r_{\mathrm{a}}$ can be mainly explained by the friction velocity which on turn depended on the surface roughness length for momentum transport $\left(z_{O m}\right)$. In wine grape, the vertical trellis system affected the roughness parameters according to the wind direction. The overhead trellis system in table grape was - due to the sheltering effect - less sensitive to wind direction. The experimental data showed that for sparse canopies, $z_{0 m}$ being $9 \%$ of the vegetation height is a doable operational rule for the semi-arid region of São Francisco River basin. For large spacing between clumps of caatinga, $z_{O m}$ is reduced in comparison with irrigated fruit trees.

The $r_{\mathrm{s}}$ values for wet surfaces are dominantly affected by atmospheric water vapour pressure deficit $(D)$ and soil moisture $(\theta)$. There was a negative physiological feedback from $D$ on evapotranspiration rates: while high $D$ values increased the gradient of water vapour transport, it at the same time created an extra blockade on the vapour flow path by partially closing the stomata. This negative feedback prevented vineyards and mango orchards from exhaling large quantities of water vapour what controls transpiration fluxes and increases the crop water productivity. Natural vegetation also showed a link between $r_{\mathrm{s}}$ and $D$ but less than for irrigated crops; for long period, $r_{\mathrm{s}}$ in natural vegetation is determined predominantly by moisture conditions. The availability of analytical methods to assess $r_{\mathrm{a}}$ and $r_{\mathrm{s}}$ makes the one-step Penman-Monteith equation suitable for actual evapotranspiration and water productivity estimations. By further developing of methods to parameterize crop production at the regional scale, it will become feasible to estimate water productivity variations and detect areas where water saving in agriculture could be realized.

\section{Acknowledgments}

The research herein was supported by CAPES (Ministry of Education - Brazil), and Embrapa (Brazilian Agricultural Research Corporation). CAPES is funding a PhD Grant for the first author. Embrapa is acknowledged for the resources to design and execute the field measurements.

\section{References}

Allen, R.G., Pereira, L.S., Raes, D., Smith, M., 1998. Crop evapotranspiration. Guidelines for computing crop water requirements. FAO Irrigation and Drainage Paper 56, Rome, Italy, 300pp.

Allen, R.G., Hartogensis, O., de Bruin, H.A.R., 2000. Long-wave radiation over alfalfa during the RAPID field campaign in southern Idaho. Research Report, Kimberly, University of Idaho, ID.

Allen, R.G., Tasumi, M., Morse, A., Trezza, 2007. Satellite-based energy balance for mapping evapotranspiration with internal- 
ized calibration (METRIC) - model. J. Irrig. Drain. Eng. ASCE, 380-394.

Azevedo, P.V., Teixeira, A.H., da Silva, B.B., Soares, J.M., Saraiva, F.A.M., 1997. Avaliação da reflectância e do saldo de radiação sobre um cultivo de videira européia. Rev. Bras. de Agrometorol. 5, 1-7.

Baldochi, D.D., Xu, L.K., Kiang, N., 2004. How plant functionaltype, weather, seasonal drought, and soil physical properties alter water and energy fluxes of an oak-grass savanna and an annual grassland. Agric. For. Meteorol. 123, 13-39.

Bastiaanssen, W.G.M., 1995. Regionalization of surface flux densities and moisture indicators in composite terrain: a remote sensing approach under clear skies in Mediterranean climates. $\mathrm{PhD}$ dissertation. CIP Data Koninklijke Bibliotheek, Den Haag, The Netherlands. 273pp.

Bastiaanssen, W.G.M., Bandara, P., 2001. Evaporative depletion assessments for irrigated watersheds in Sri Lanka. Irr. Sci. 21, 115.

Brunt, D., 1939. Physical and Dynamical Meteorology. Cambridge University Press.

Brutsaert, W., Sugita, M., 1992. Application of self-preservation in the diurnal evolution of the surface energy budget to determine daily evaporation. J. Geophys. Res. 97 (D17), 18377-18382.

Campbell, G.S., Norman, J.M., 1998. An Introduction to Environmental Biophysics. Springer, New York, p. 286.

Chehbouni, A., Nouvellon, Y., Lhomme, J.-P., Watts, C., Boulet, G., Kerr, Y.H., Moran, M.S., Goodrich, D.C., 2001. Estimation of surface sensible heat flux using dual angle observations of radiative surface temperature. Agri. Forest Meteorol. 108, 5565.

Crago, R.D., 1996. Comparison of the evaporative fraction and the Priestley-Taylor $\alpha$ for parameterizing daytime evaporation. Water Resour. Res. 32 (5), 1403-1409.

de Bruin, H.A.R., 1987. From Penman to Makkink. In: Hooghart, J.C. (Ed.), Proceedings and Information: TNO Committee on Hydrological Sciences, vol. 39. Gravenhage, The Netherlands, pp. 531.

de Bruin, H.A.R., Stricker, J.N.M., 2000. Evaporation of grass under non-restricted soil moisture conditions. Hydrological SciencesJournal-des Sciences Hydrologiques 45 (3), 391-406.

Dolman, A.J., 1992. A note on areally-averaged evaporation and the value of the effective surface conductance. J. Hydrol. 138, 583589.

Driese, K.L., Reiners, W.A., 1997. Aerodynamic roughness parameters for semi-arid natural shrub communities of Wyoming, USA. Agri. Forest Meteorol. 88, 1-14.

Farah, H.O., Bastiaanssen, W.G.M., 2004. Evaluation of the temporal variability of the evaporative fraction in a tropical watershed. Int. J. Appl. Earth Obs. Geoinf. 5, 129-140.

Garrat, J.R., Hicks, B.B., 1973. Momentum, heat and water vapour transfer to and from natural and artificial surfaces. Q.J.R. Meteorol. Soc. 99, 680-687.

Garrat, J.R., 1978. Transfer characteristics for a heterogeneous surface of large aerodynamics roughness. Q.J.R. Meteorol. Soc. 104, 491-502.

Gash, J.H.C., Shuttleworth, W.J., 2007. Evaporation, selection, introduction and commentaries. Sahra benchmark papers in hydrology, IAHS. ISBN 978-901502-98-5.

Hatfield, J.L., 1985. Wheat canopy resistance determined by energy balance techniques. Agron. J. 77 (2), 279-283.

Heilman, J.L., Mcinnes, K.J., Savage, M.J., Gesh, R.W., Lascano, R.J., 1994. Soil and canopy energy balances in a West Texas vineyard. Agri. Forest Meteorol. 71, 99-114.

Heilman, J.L., Mcinnes, K.J., Gesh, R.W., Lascano, R.J., Savage, M.J., 1996. Effects of trellising on the energy balance of the vineyard. Agri. Forest Meteorol. 81, 79-93.

Hicks, B.B., 1973. Eddy fluxes over a vineyard. Agri. Meteorol. 12, 203-215.
Hughes, C.E., Kalma, J.D., Binning, P., Willgoose, G.R., Vertzonis, M., 2001. Estimating evapotranspiration for a temperate salt marsh Newcastle, Australia. Hydrol. Process. 15, 957-975.

Jarvis, P.G., 1976. The interpretation of the variations in leaf water potential and stomatal conductance found in canopies in the field. Phil. Trans. R. Soc. Lond., Ser. B. 273, 593-610.

Kite, G.W., Droogers, P., 2000. Comparing evapotranspiration estimates from satellites, hydrological models and field data. J. Hydrol. 229, 3-18.

Kustas, W.P., Perry, E.M., Doraiswamy, P.C., Moran, M.S., 1994. Using satellite remote sensing to extrapolate evapotranspiration estimates in time and space over a semiarid rangeland basin. Rem. Sens. Environ. 49, 275-286.

Li, S.-G., Eugster, W., Asanuma, J., Kotani, A., Davaa, G., Oyunbaatar, D., Sugita, M., 2006. Energy partitioning and its biophysical controls above a grazing steppe in central Mongólia. Agri. Forest Meteorol. 137, 89-106.

Lobell, D.B., Asner, G.P., 2002. Moisture effects on soil reflectance. Soil Sci. Am. J. 66, 722-727.

Lund, M.R., Soegaard, H., 2003. Modeling of evaporation in a sparse millet using a two source model including sensible heat advection within the canopy. J. Hydrol. 280, 124-144.

Makkink, G.F., 1957. Testing the Penman formula by means of lysimeters. J. Int. Water Eng. 11, 277-288.

Monteith, J.L., 1973. Principles of Environmental Physics. Elsevier, New York.

Monteith, J.L., Unsworth, M.H., 1990. Principles of Environmental Physics, second ed. Edward Arnold, London, p. 291.

Novello, V., Schubert, A., Antonietto, M., Boschi, A., 1992. Water relations of grapevine $\mathrm{cv}$. Cortese with different training systems. Vitis $31,65-75$.

Oguntoyinbo, J.S., 1970. Reflection coefficient of natural vegetation, crops and urban surfaces in Nigeria. Q.J.R. Soc. Meteorol. 96, 430-441.

Oliver, H.R., Sene, K.J., 1992. Energy and water balances of developing vines. Agri. Forest Meteorol. 61, 167-185.

Pinker, R.T., Thompson, O.E., Eck, T.F., 1980. The albedo of a tropical evergreen forest. Q.J.R. Meteorol. Soc. 106, 551-558.

Rana, G., Katerji, N., Michele, I.M., Hammami, A., 2004. Microclimate and plant water relationship of the overhead table grape vineyard managed with three different covering techniques. Sci. Hortic. 102, 105-120.

Riddersma, S., De Ridder, N., 1996. Computed evapotranspiration of annual and perennial crops at different temporal and spatial scales using published parameter values. Agri. Water Manage. 31, 17-34.

Riou, C., Pieri, P., Valancogne, C., 1987. Variation de la vitesse du vent a línterieur et au-dessus dúne vigne. Agri. Forest Meteorol. $39,143-154$

Sene, K.J., 1994. Parameterizations for energy transfers from a sparse vine crop. Agri. Forest Meteorol. 71, 1-18.

Shuttleworth, W.J., 1988. Evaporation from Amazonian rain forest. Proc. Royal Soc. (London) B 233, 321-346.

Stewart, J. B. 1989. On the use of the Penman-Monteith equation for determining areal evapotranspiration. 3-2. In: Black, T.A., Spittlehouse, D.L., Novak, M.D., Price, D.T. (Eds.), Estimation of Areal Evapotranspiration, IAHS, Pub. No. 177.

Su, Z., 2002. The surface energy balance system (SEBS) for estimation of turbulent heat fluxes. Hydrol. Earth Syst. Sci. 6, 85-99.

Swinbank, W.C., 1963. Longwave radiation from clear skies. Q.J.R. Meteorol. Soc. 89, 339-348.

Thom, A.S., 1972. Momentum, mass and heat exchange of vegetation. Q.J.R. Meteorol. Soc. 98, 124-134.

Troufleau, D., Lhomme, J.P., Monteny, B., Vidal, A., 1997. Sensible heat flux and radiometric surface temperature over sparse Sahelian vegetation. I. An experimental analysis of the $\mathrm{kB}^{-1}$ parameter. J. Hydrol. 188-189, 815-838. 
Van Bavel, C.H., 1967. Changes in canopy resistance to water loss from alfalfa induced by soil water depletion. Agri. Meteorol. 4, 165-176.

Van den Hurk, B.J.J.M., Verhoef, A., vand den Berg, A.R., de Bruin, H.A.R., 1996. An intercomparison of three vegetation/soil models for a sparse vineyard canopy. Q.J.R. Meteorol. Soc. 121, 1889-1967.

Van Dijk, A.I.J.M., Bruijnzeel, L.A., Schellekens, J., 2004. Micrometeorology and water use of mixed crops in upland West Java, Indonesia. Agri. Forest Meteorol. 124, 31-49.
Wang, K., Li, Z., Cribb, M., 2007. Estimation of evaporative fraction from a combination of day and night land surface temperatures and NDVI: a new method to determine the Priestly-Taylor parameter. Rem. Sens. Environ. 102, 293-305.

Yunusa, I.A.M., Walker, R.R., Lu, P., 2004. Evapotranspiration components from energy balance, sapflow and microlysimetry techniques for an irrigated vineyard in inland Australia. Agri. Forest Meteorol. 127, 93-107. 